NBER WORKING PAPER SERIES

\title{
PRODUCTIVITY GROWTH IN MANUFACTURING \\ DURING EARLY INDUSTRIALIZATION: \\ EVIDENCE FROM THE AMERICAN \\ NORTHEAST, 1820 TO 1860
}

\author{
Kenneth L. Sokoloff
}

Working Paper No. 1685

\section{NATIONAL BUREAU OF ECONOMIC RESEARCH \\ 1050 Massachusetts Avenue \\ Cambridge, MA 02138 \\ August 1985}

The research reported here is part of the NBER's research program in Development of the American Economy. Any opinions expressed are those of the author and not those of the National Bureau of Economic Research. 


\section{Productivity Growth in Manufacturing \\ During Early Industrialization: \\ Evidence from the American \\ Northeast, 1820 to 1860}

\section{ABSTRACT}

This paper reports estimates of labor and total factor productivity, for thirteen manufacturing industries in the Northeast over the period from 1820 to 1860 . It finds that although the highly mechanized and capital-intensive industries, such as cotton and wool textiles, realized somewhat more rapid progress than the others did, even the latter managed mojor advances. The evidence appears to support the conclusion that the manufacturing sector in the Northeast was quite dynamic during this stage of industrialization, and that much of its early productivity growth can be explained by changes in production processes that did not require mechanization or substantial increases in capital intensity. This suggests, as has been argued by number of recent studies building on an old tradition, that developments such as increases in the division and intensity of labor within firms and other relatively subtle alterations in technique, perhaps stimulated by the expansion of markets, may have played important roles in accounting for the progress achieved.

Renneth L. Sokoloff Department of Economics University of California, Los Angeles Los Angeles, CA 90024 
It has long been recognized that industrialization got under way in the U. S. early in the nineteenth century, and was largely concentrated in the Northeast throughout the antebellum period. The dramatic sectoral reallocation of resources that accompanied this process is generally acknowledged to have yielded a significant gain in measured per capita income, if only because resources in that region were more productive in industries other than agriculture. The extent of productivity growth within sectors, however, remains unclear. This gap in our knowledge has been a serious obstacle to improving our understanding of this initial phase of industrialization, because the record of productivity is so closely related to issues of the sources, location, timing, and nature of this episode in American economic growth.

Evidence on the progress realized in manufacturing, in particular, would have a direct bearing on whether the surge of rapid industrial expansion in the Northeast was driven by dynamic manufacturing industries that were generating sustained increases in productivity and income, or by a declining agricultural sector that was finding it increasingly difficult to compete with producers outside the region. Moreover, industry-specific estimates would help determine to what degree early productivity growth in manufacturing was linked to capital deepening or capital-augmenting innovations. Some scholars have suggested that these factors were virtual prerequisites for major gains 
in productivity, while others have emphasized that changes in the organization of labor, increases in the intensity of work, and other alterations in production processes that were not dependent on additional capital equipment per unit of labor may have been important sources of measured advances (Chandler, 1977; David, 1975; Landes, 1969, 1985; Lazonick and Brush, 1985; Marglin, 1974; Sokoloff, 1984b).

Despite the clear significance of the issues involved, there have been few studies of productivity growth during early 0 . S. industrialization due to the relative inaccessibility of evidence. 1 Recently-collected samples of firm data from the schedules of the 1820 Census of Manufactures and the McLane Report of 1832 provide valuable new sources of information however (Sokoloff, 1982). Employing these bodies of evidence in conjunction with the Bateman-Weiss samples of firms from the schedules of both the 1850 and the 1860 Census of Manufactures, and the aggregate data from those censuses, this paper seeks to establish the record of productivity growth in northeastern manufacturing during this critical period of industrial development. These sources are not without flaws, but the richness of the information they contain make them together an unequalled collection of material for reserch on the subject. All of them provide reports of the value of outputs produced and the quantity or value of inputs utilized, and thus indexes of productivity can be estimated for many industries in each of the four years. Perhaps the primary concern involving the quality of the data, is that the firms included in the four cross-sectional samples from the manufacturing survey and censuses 
may not be representative of the population of northeastern monufacturing firms during the respective years. ${ }^{2}$ Problems of the representativeness of data are always a serious matter and require special care in conducting the analysis. Nevertheless, as will be discussed below, the sample selection biases that afflict these bodies of evidence eem unlikely to be responsible for the qualitative results uncovered.

This peper reports estimstes of labor and total factor productivity, for thirteen manufacturing industries in the Northeast over the period from 1820 to 1860 . It finds that although the highly mechanized and capital-intensive industries, uch as cotton and wool textiles, realized sowewhat more rapid progress than the others did, even the latter managed major advances. The evidence appears to support the conclusion that the manfacturing sector in the Northesst was quite dyomic during this stage of industrialization, and that much of its early productivity growth can be explained by changes in production processes that did not require mechanization or substantial increases in capital intensity. This suggests, as has been argued by a number of recent studies building on an old tradition, that developments such as increases in the division and intensity of labor within firms and other relatively abtle alterations in technique, perhape stimulated by the expansion of markets, may have played important roles in accounting for the progress achieved.

Estimates of labor productivity over the period are presented in section II of the paper. The procedures employed in 
constructing them are discussed in some detail, and although they vere consciously designed to gield conservative estimates of the increase in productivity, weighted averages indicate rates of labor productivity growth that are quite high by nineteenth- or twentieth-century standards. There is evidence of an acceleration in the pace of advance, particularly in the less machanized and capital-intensive industries. Estimates of total factor productivity are presented in section III. They reveal that if one treats firm valuations of their capital investments as relatively accurate asessments of the capital input, as it is contended bere that one should, the data imply that most manufacturing industries realized large gains in total factor productivity over the period. As all classes of industries appear to have manifested imilar rates of progress, doubt about the primacy of capital deepening or capital intensity in generating productivity growth are reinforced. Moreover, the estimsted advances are of such a magnitude that they appear to account, together with increases in the ratio of raw msterials to labor, for nearly all of the rise in labor productivity. Some general remarks on what these findings suggest imply about the early atages of industrialization in the 0 . S. are offered in section IV. 
There are at least several reasons why the record of labor productivity deserves separate treatment from that of total factor productivity. Perhape the major one is that movements in labor productivity convey information about the evolution of production methods that is not generally contained in the more comprehensive measure. Since several of the most important ibsues relating to the development of manufacturing technology during earls industrialization concern the direction and extent of changes in factor proportions, it would seem desirable to examine both labor and total factor productivity. The availability of the two series is also useful in that investigation of apparent inconsistencies between them can help to identify problems with the data or of interpretation. Finally, it might be argued that because movements in output per unit of labor are more closely related to those in per capita income, establishing the record of labor productivity, even in only this single sector of the economy, would by itself directly contribute to our understanding of economic growth during this critical period. The ccounting exercise of decomposing the responsibility for increases in labor productivity between changes in factor proportions and total factor productivity, for example, may yield results suggestive of what imilar calculations for per capita income would indicate.

Two measures of labor productivity are employed here, value added per equivalent worker and gross output per equivalent vorker. 
Estimstes expressed in current dollars are presented in Tables 1 and 2 , respectively, for thirteen industries at the years 1820, 1832, 1850 , and 1860 . The industries examined vere selected 10 as to cover botb the major ones of the period and a broad cross-section of the manufacturing sector, Bubject to the limitations imposed by the need for each industry to be reasonably vell represented in the samples of manufacturing firm data and a desire to maintain conventional industrial classifications. ${ }^{3}$ Some industries do not bave estimates of productivity reported for certain years, becaube of an inadequate number of observations, but the threshold for incluaion was set to keep the number of omissions low.

Three sets of estimates, $\underline{A}, \underline{B}$, and $\underline{C}$, are reported for each industry. They are computed over different oubsets of firms, with the variation in composition attributable to the progressive application of increasingly stringent atandards for eeparating establishments likely to be operating part-time from those in full-time production. Part-time enterprises should be excluded from the subsamples over vich the estimates are prepared, because the measured productivity levels of ouch firms are biased downard due to the general practice of reporting the average labor input over the period in operation, rather than over the entire year. 4 since these firms generally failed to explicitly identify themselves, several methods of ordering the establishments by their probability of being part-time operators, so that elected proportions could be dropped from the Bubsamples over which productivity was estimated, were applied to the 
TABLE 1

Nowinal Palue Added per Equivalent Worker is Selected Manufacturing Industries: 1820 to 1860

\begin{tabular}{|c|c|c|c|c|c|c|c|c|}
\hline & & 1820 & 183 & 32 & $\begin{array}{l}1850 \\
(f i r m s)\end{array}$ & $\begin{array}{l}1850 \\
(288 .)\end{array}$ & $\begin{array}{l}1860 \\
\text { (firms) }\end{array}$ & $\begin{array}{l}1860 \\
(988 .)\end{array}$ \\
\hline Boots/Shoes & $\begin{array}{l}\mathbf{A} \\
\mathbf{B} \\
\mathbf{C}\end{array}$ & $\begin{array}{r}\$ 276.0(22) \\
323.3(17) \\
350.0(15)\end{array}$ & $\overline{-}$ & & $\begin{array}{r}\$ 283.5(254) \\
290.1(247) \\
306.7(207)\end{array}$ & $\$ 305.4(8110)$ & $\begin{array}{r}\$ 430.7(170) \\
434.2(161) \\
454.7(133)\end{array}$ & $\$ 421.7(7326)$ \\
\hline $\begin{array}{l}\text { Coaches/ } \\
\text { Esrnesses }\end{array}$ & $\begin{array}{l}\mathbf{A} \\
\mathbf{B} \\
\mathbf{C}\end{array}$ & $\begin{array}{l}473.7(33) \\
490.5(31) \\
502.5(28)\end{array}$ & $\begin{array}{r}\$ 330.6 \\
359.6 \\
368.9\end{array}$ & $\begin{array}{l}(36) \\
(35) \\
(32)\end{array}$ & $\begin{array}{l}388.4(96) \\
461.5(88) \\
464.2(77)\end{array}$ & $435.4(2635)$ & $\begin{array}{l}691.4(122) \\
697.5(118) \\
645.8(98)\end{array}$ & $600.1(5057)$ \\
\hline $\begin{array}{l}\text { Cotton } \\
\text { Textiles }\end{array}$ & $\begin{array}{l}\mathbf{A} \\
\mathbf{B} \\
\mathbf{C}\end{array}$ & $\begin{array}{l}352.8(64) \\
391.0(45) \\
457.8(25)\end{array}$ & $\begin{array}{l}504.3 \\
505.5 \\
513.6\end{array}$ & $\begin{array}{l}(76) \\
(75) \\
(69)\end{array}$ & $\begin{array}{l}322.3(24) \\
326.5(23) \\
390.2(18)\end{array}$ & $460.0(856)$ & $\begin{array}{l}494.9(23) \\
494.9(23) \\
618.6(20)\end{array}$ & $772.7(840)$ \\
\hline $\begin{array}{l}\text { Furaiture/ } \\
\text { boodwork }\end{array}$ & $\begin{array}{l}\mathbf{A} \\
\mathbf{C}\end{array}$ & $\begin{array}{l}395.0(25) \\
434.2(21) \\
496.5(15)\end{array}$ & $\begin{array}{l}359.9 \\
364.6 \\
384.3\end{array}$ & $\begin{array}{l}(26) \\
(25) \\
(22)\end{array}$ & $\begin{array}{l}380.6(48) \\
421.7(46) \\
426.7(39)\end{array}$ & $517.3(2299)$ & $\begin{array}{l}664.7(42) \\
695.8(38) \\
722.2(31)\end{array}$ & $674.5(1804)$ \\
\hline 62283 & $\begin{array}{l}\mathbf{A} \\
\mathbf{B} \\
\mathbf{C}\end{array}$ & $\begin{array}{l}488.3(3) \\
488.3(3) \\
519.6(2)\end{array}$ & $\begin{array}{l}767.2 \\
767.2 \\
753.8\end{array}$ & $\begin{array}{l}(6) \\
(6) \\
(5)\end{array}$ & $=$ & $593.5(77)$ & $\begin{array}{l}- \\
-\end{array}$ & $682.1(79)$ \\
\hline Bat: & $\begin{array}{l}\mathbf{A} \\
\mathbf{B} \\
\mathbf{C}\end{array}$ & $\begin{array}{l}417.6(27) \\
485.5(22) \\
413.8(19)\end{array}$ & $\begin{array}{l}541.3 \\
541.3 \\
558.5\end{array}$ & $\begin{array}{l}(13) \\
(13) \\
(10)\end{array}$ & $\begin{array}{l}591.1(17) \\
595.7(16) \\
631.9(12)\end{array}$ & $633.3(814)$ & $\begin{array}{l}788.9(13) \\
788.9(13) \\
776.6(11)\end{array}$ & $808.2(281)$ \\
\hline Iron & $\begin{array}{l}\mathrm{A} \\
\mathrm{C}\end{array}$ & $\begin{array}{l}350.4(32) \\
585.4(21) \\
593.6(15)\end{array}$ & $\begin{array}{l}- \\
-\end{array}$ & & $\begin{array}{l}328.9(36) \\
443.8(33) \\
479.3(28)\end{array}$ & $470.5(1494)$ & $\begin{array}{l}564.1(23) \\
613.6(21) \\
702.5(15)\end{array}$ & $648.1(1288)$ \\
\hline iquors & $\begin{array}{l}\mathbf{A} \\
\mathbf{B} \\
\mathbf{C}\end{array}$ & $\begin{array}{l}530.0(177) \\
640.7(132) \\
667.1(107)\end{array}$ & $\begin{array}{l}- \\
-\end{array}$ & & $\begin{array}{l}635.8(7) \\
699.7(6) \\
793.8(4)\end{array}$ & $1052.5(633)$ & $\begin{array}{l}1262.6(13) \\
1339.7(12) \\
1514.3(10)\end{array}$ & $1469.4(922)$ \\
\hline $\begin{array}{l}\text { Flourl } \\
\text { Criet Millo }\end{array}$ & $\begin{array}{l}\mathbf{A} \\
\mathbf{B} \\
\mathbf{C}\end{array}$ & $\begin{array}{l}442.8(70) \\
566.1(45) \\
638.8(34)\end{array}$ & $\overline{-}$ & & $\begin{array}{l}330.0(109) \\
549.3(104) \\
672.7(64)\end{array}$ & $689.7(5128)$ & $\begin{aligned} 846.1(105) \\
900.4(97) \\
1051.3(64)\end{aligned}$ & $906.4(4964)$ \\
\hline Paper & $\begin{array}{l}\mathbf{A} \\
\mathbf{B} \\
\mathbf{C}\end{array}$ & $\begin{array}{l}426.0(23) \\
432.1(22) \\
445.7(20)\end{array}$ & $\begin{array}{l}582.6 \\
582.6 \\
618.4\end{array}$ & $\begin{array}{l}(27) \\
(27) \\
(23)\end{array}$ & $\begin{array}{l}982.0(20) \\
982.0(20) \\
909.8(18)\end{array}$ & $913.2(361)$ & $\begin{array}{l}706.4(20) \\
720.3(19) \\
817.0(14)\end{array}$ & $1128.9(472)$ \\
\hline Ding & $\begin{array}{l}\mathbf{A} \\
\mathbf{B} \\
\mathbf{C}\end{array}$ & $\begin{array}{l}331.8(120) \\
419.0(76) \\
499.9(47)\end{array}$ & $\begin{array}{l}582.2 \\
588.0 \\
543.2\end{array}$ & $\begin{array}{l}(45) \\
(43) \\
(33)\end{array}$ & $\begin{array}{l}511.7(98) \\
531.0(92) \\
562.1 \quad(65)\end{array}$ & $761.3(3256)$ & $\begin{array}{l}803.3(77) \\
825.7(69) \\
896.0(53)\end{array}$ & $1033.5(2670)$ \\
\hline bacco & $\begin{array}{l}A \\
\mathbf{B} \\
\mathbf{C}\end{array}$ & $\begin{array}{l}373.4(8) \\
466.4(7) \\
517.9(5)\end{array}$ & $\overline{-}$ & & $\begin{array}{l}312.8(15) \\
312.8(15) \\
360.7(12)\end{array}$ & $240.1(628)$ & $\begin{array}{l}733.7(12) \\
733.7(12) \\
744.8(11)\end{array}$ & $667.1(918)$ \\
\hline $\begin{array}{l}\text { Yool } \\
\text { Iextiles }\end{array}$ & $\begin{array}{l}\hat{A} \\
\mathbf{c}\end{array}$ & $\begin{array}{l}373.4(53) \\
466.4(35) \\
571.9(19)\end{array}$ & $\begin{array}{l}650.9 \\
651.7 \\
652.0\end{array}$ & $\begin{array}{l}(59) \\
(58) \\
(48)\end{array}$ & $\begin{array}{l}730.7(42) \\
739.2(40) \\
738.8(35)\end{array}$ & $563.2(1375)$ & $\begin{array}{l}871.5(23) \\
871.5(23) \\
840.7(20)\end{array}$ & $849.7(1041)$ \\
\hline
\end{tabular}


Table 1

Notes and Sources: The firm-level estimates were computed from the samples of northeastern manufacturing firm data drawn from the schedules of the 1820,1850 , and 1860 Federal Censuses of Manufactures and the Mclane Report ( 0 . S. House of Representatives, 1832). The aggregate estimates were computed from the industry-wide information reported by tate in 0 . S. Census office (1858, 1865). The figures reported for 1832,1850 , and 1860 are based on information that probably pertains primarily to the operations of firms in 1831,1849, and 1859 respectively. The eatimates were calculated as the ratio of the industry value added (or the value of output minus the cost of the Iaw materials) to the total number of equivalent adult male vorkers in the industry. The number of equivalent workers was computed according to the formulation: $T E=M+0.5(F+B)+E$, where $T E$ is the number of equivalent adult male workers, $Y$ is the number of adult male employees, $F$ and $B$ are the numbers of female and boy employees respectively, and $\mathrm{E}$ is set equal to one per firm as the measure of the entrepreneurial input. In 1850 and 1860 , firms generelly did not separately enumerate adult males and boys. Accordingly, the reported numbers of male employees in those years were decomposed into adults and boys by assuming that boys accounted for the same proportions, by industry, of male employees as they had in 1820 . In those industries in which boys had accounted for more than 33 percent of male employees in 1820 , it was further asumed that the shares had been reduced to 33 
percent by 1850 and 1860 .

The estimates based on firm data were computed orer cub-samples from the various years that have observations deleted from them in order to control for the effects of establishments that operated only part-time and other outliers. The method adopted to identify potential part-time firms utilized two distributions of firms for each gear by total factor productivity, one computed with grose output as the measure of output (IFP) and the otber treating value added as that measure (NFP). The guiding principle was that the lower the total factor productivity of a firm in given year, the more likely the firm was part-time operation and hould be truncated from the sub-sample of establisbments over which the productivity estimates vere computed.

Three sets of productivity estimates have been prepared from three corresponding sets of firm sub-samples. The sets of sub-samples vary in composition by the successive truncation made primarily to exclude part-time firms from the calculations. The $A$ set of estimstes were computed over ub-samples of firms witb no adjustments for part-time operstors. The establishments dropped from the samples of firms that reported all of the necessary information and did not explicitly identify themselves a part-time enterprises to obtain the $\underline{A}$ sub-samples included those with negative value added, few other large outliers, and those who ploced in the top 3 percent of enterprises in the respective years by both measures of total factor productivity. These criteria led to 4 percent being truncated from the 1820 ample, 3 percent from that in 1832,5 percent in 1850 , and 4 percent from the 
sample in 1860.

Set $\underline{B}$ is based on more severe truncations of the left-tails of the distributions of firms by total factor productivity. For the 1820 sub-sample, establishments thet ranked in the lowest 30 percent by both measures of total factor productivity were dropped from aub-sample $\underline{A}$ to get $\underline{B}$. The corresponding percentages vere 5 percent in 1832,10 percent in 1850 , and 10 percent in 1860 . The smaller proportions truncated from the samples of later gears refilect the presumed decline over time in the fraction of firms operating part-time, as vell as the desire to bias the estimated productivity growtb rate downard. In order to achieve this latter goal, one would seek to overestimate the proportion of establishments in 1820 that operated part-time, and underestimate the proportion in 1860. A particularly amall proportion was dropped from the 1832 sample because enumerators from the Mclane Report indicated that nearly all of the establishments covered from tbe states considered bere vere operating throughout the year. The total proportions of firms excluded frow the entire samples to obtain set $\underline{B}$ vere 29 percent in 1820,5 percent in 1832,9 percent in 1850 , and 10 percent in 1860 .

For set $\underline{C}$, even larger fractions of the firms in the samples were truncated. Firms tbat, by either messure of total factor productivity, were in the bottom 40 percent of the 1820 sample vere left out of the sub-sample tbat was the basis for the $\underline{c}$ estimates of that year. The corresponding threshold points for truncation from the $\underline{C}$ ab-samples for the other years are 10 percent for 1832,20 percent 
for 1850 , and 20 percent for 1860 . In addition, those establisbments that were in the top 3 percent of firms by either measure of total factor productivity in their respective years, and had not already been dropped from the $A$ and $\underline{B}$ sub-samples, vere also truncated to produce the $\underline{C}$ sub-samples. These criteris led to 48 percent being truncated from the 1820 saple, 17 percent from that of 1832,28 percent from that of 1850 , and 29 percent from that of 1860 .

The numbers appearing within parentheses aignify the number of observations on which the respective estimate is based. No estimates are reported for years in which there vere less than three observation in the $\underline{A}$ oub-sample. The only industry vhose estimstes are based on such limited number of firms is glass, but in this case the ceveral firms appearing in the 1820 sample account for a subtantial proportion of the regionsl output. Ho estimates are reported for the boots/shoes industry in 1832 , because lerge proportion of the firms in the sample frow that year were putting-out establishments. 
TABLE 2

Nowinal Gros: Output per Equivaledt Worker in Selected Manufacturing Industries: 1820 to 1860

\begin{tabular}{|c|c|c|c|c|c|c|c|c|c|c|c|}
\hline \multirow[b]{2}{*}{$\begin{array}{l}\text { Boots/ } \\
\text { Shoes }\end{array}$} & \multirow[b]{2}{*}{$\begin{array}{l}\mathrm{A} \\
\mathrm{B} \\
\mathrm{C}\end{array}$} & \multicolumn{2}{|c|}{1820} & \multicolumn{2}{|c|}{1832} & \multicolumn{2}{|c|}{$\begin{array}{l}1850 \\
\text { (firms) }\end{array}$} & \multicolumn{2}{|c|}{$\begin{array}{l}1850 \\
(488 .)\end{array}$} & $\begin{array}{l}1860 \\
(f i \text { irso })\end{array}$ & $\begin{array}{l}1860 \\
(288 .)\end{array}$ \\
\hline & & $\begin{array}{r}\$ 517.6 \\
581.2 \\
594.6\end{array}$ & $\begin{array}{l}(22) \\
(17) \\
(15)\end{array}$ & $\overline{-}$ & & $\begin{array}{r}\$ 556.8 \\
564.1 \\
593.7\end{array}$ & $\begin{array}{l}(254) \\
(247) \\
(207)\end{array}$ & $\$ 563.0$ & $(8110)$ & $\begin{array}{r}\$ 904.2(170) \\
910.1(161) \\
940.7(133)\end{array}$ & $\$ 803.6(7326)$ \\
\hline $\begin{array}{l}\text { Coaches/ } \\
\text { Earnesses }\end{array}$ & $\begin{array}{l}\mathbf{A} \\
\mathrm{B} \\
\mathbf{C}\end{array}$ & $\begin{array}{l}873.8 \\
904.6 \\
928.1\end{array}$ & $\begin{array}{l}(33) \\
(31) \\
(28)\end{array}$ & $\begin{array}{r}\$ 574.4 \\
614.0 \\
622.1\end{array}$ & $\begin{array}{l}(36) \\
(35) \\
(32)\end{array}$ & $\begin{array}{l}765.9 \\
902.4 \\
932.3\end{array}$ & $\begin{array}{l}(96) \\
(88) \\
(77)\end{array}$ & 763.4 & (2635) & $\begin{array}{l}1175.8(122) \\
1184.2(118) \\
1136.4(98)\end{array}$ & $987.5(5057)$ \\
\hline $\begin{array}{l}\text { Cotton } \\
\text { Textiles }\end{array}$ & $\begin{array}{l}\mathbf{A} \\
\mathrm{B} \\
\mathrm{C}\end{array}$ & $\begin{array}{l}668.4 \\
721.6 \\
796.7\end{array}$ & $\begin{array}{l}(64) \\
(45) \\
(25)\end{array}$ & $\begin{array}{l}927.7 \\
928.6 \\
933.7\end{array}$ & $\begin{array}{l}(76) \\
(75) \\
(69)\end{array}$ & $\begin{array}{l}1045.0 \\
1056.6 \\
1046.3\end{array}$ & $\begin{array}{l}(24) \\
(23) \\
(18)\end{array}$ & 1073.7 & (856) & $\begin{array}{l}1053.2(23) \\
1053.2(23) \\
1574.0(20)\end{array}$ & $1497.0(840)$ \\
\hline $\begin{array}{l}\text { Furaiture/ } \\
\text { Woodwork }\end{array}$ & $\begin{array}{l}\mathrm{A} \\
\mathrm{B} \\
\mathrm{C}\end{array}$ & $\begin{array}{l}629.2 \\
665.1 \\
760.5\end{array}$ & $\begin{array}{l}(25) \\
(21) \\
(15)\end{array}$ & $\begin{array}{l}677.3 \\
685.8 \\
721.0\end{array}$ & $\begin{array}{l}(26) \\
(25) \\
(22)\end{array}$ & $\begin{array}{l}724.4 \\
742.3 \\
762.5\end{array}$ & $\begin{array}{l}(48) \\
(46) \\
(39)\end{array}$ & 830.9 & (2299) & $\begin{array}{l}1023.8(42) \\
1064.0(38) \\
1096.5(31)\end{array}$ & $1027.4(1804)$ \\
\hline GIE:6 & $\begin{array}{l}\text { A } \\
\text { B } \\
\text { C }\end{array}$ & $\begin{array}{l}676.0 \\
676.0 \\
727.2\end{array}$ & $\begin{array}{l}(3) \\
(3) \\
(2)\end{array}$ & $\begin{array}{l}1300.4 \\
1300.4 \\
1299.6\end{array}$ & $\begin{array}{l}(6) \\
(6) \\
(5)\end{array}$ & $\overline{-}$ & & 879.4 & (77) & 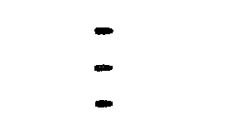 & $1030.5(79)$ \\
\hline Bats & $\begin{array}{l}\mathbf{A} \\
\mathrm{B} \\
\mathrm{C}\end{array}$ & $\begin{array}{l}796.2 \\
899.3 \\
816.7\end{array}$ & $\begin{array}{l}(27) \\
(22) \\
(19)\end{array}$ & $\begin{array}{l}1027.5 \\
1027.5 \\
1061.2\end{array}$ & $\begin{array}{l}(13) \\
(13) \\
(10)\end{array}$ & $\begin{array}{l}1329.0 \\
1338.7 \\
1377.2\end{array}$ & $\begin{array}{l}(17) \\
(16) \\
(12)\end{array}$ & 1278.2 & $(814)$ & $\begin{array}{l}1866.6(13) \\
1866.6(13) \\
1868.1(11)\end{array}$ & $1605.3(281)$ \\
\hline Irod & $\begin{array}{l}\mathbf{A} \\
\mathbf{B} \\
\mathbf{C}\end{array}$ & $\begin{array}{r}762.2 \\
1251.4 \\
1347.1\end{array}$ & $\begin{array}{l}(32) \\
(21) \\
(15)\end{array}$ & $\overline{-}$ & & $\begin{array}{l}745.2 \\
872.2 \\
881.7\end{array}$ & $\begin{array}{l}(36) \\
(33) \\
(28)\end{array}$ & 1030.5 & (1494) & $\begin{array}{l}1457.1(23) \\
1588.2 \text { (21) } \\
1788.9 \text { (15) }\end{array}$ & $1422.2(1288)$ \\
\hline Liquors & $\begin{array}{l}\mathbf{A} \\
\mathbf{B} \\
\mathbf{C}\end{array}$ & $\begin{array}{l}1554.5 \\
1882.1 \\
1954.0\end{array}$ & $\begin{array}{l}(177) \\
(132) \\
(107)\end{array}$ & - & & $\begin{array}{l}1454.0 \\
1606.0 \\
1806.6\end{array}$ & $\begin{array}{l}(7) \\
(6) \\
(4)\end{array}$ & 3341.0 & (633) & $\begin{array}{l}4253.9(13) \\
4508.9(12) \\
4898.0(10)\end{array}$ & $4252.1(922)$ \\
\hline $\begin{array}{l}\text { Flourl } \\
\text { Grist Mill. }\end{array}$ & $\begin{array}{l}\mathbf{A} \\
\mathbf{B} \\
\mathbf{C}\end{array}$ & $\begin{array}{l}1950.3 \\
2540.3 \\
2650.4\end{array}$ & $\begin{array}{l}(70) \\
(45) \\
(34)\end{array}$ & - & & $\begin{array}{l}3895.9 \\
4037.1 \\
4794.6\end{array}$ & $\begin{array}{l}(109) \\
(104) \\
(64)\end{array}$ & 4900.8 & $(3128)$ & $\begin{array}{l}5756.9(105) \\
6117.0(97) \\
6599.5(64)\end{array}$ & $6154.7(4964)$ \\
\hline Paper & $\begin{array}{l}\mathbf{A} \\
\mathbf{B} \\
\mathbf{C}\end{array}$ & $\begin{array}{l}667.9 \\
673.3 \\
690.2\end{array}$ & $\begin{array}{l}(23) \\
(22) \\
(20)\end{array}$ & $\begin{array}{l}1418.2 \\
1418.2 \\
1477.8\end{array}$ & $\begin{array}{l}(27) \\
(27) \\
(23)\end{array}$ & $\begin{array}{l}2153.1 \\
2153.1 \\
1953.5\end{array}$ & $\begin{array}{l}(20) \\
(20) \\
(18)\end{array}$ & 2065.8 & $(361)$ & $\begin{array}{l}1619.1(20) \\
1648.4(19) \\
1874.9(14)\end{array}$ & $2286.9(472)$ \\
\hline Ianding & $\begin{array}{l}\mathbf{A} \\
\mathbf{B} \\
\mathbf{C}\end{array}$ & $\begin{array}{r}853.5 \\
1037.0 \\
1218.7\end{array}$ & $\begin{array}{l}(120) \\
(76) \\
(47)\end{array}$ & $\begin{array}{l}1535.7 \\
1550.2 \\
1450.2\end{array}$ & $\begin{array}{l}(45) \\
(43) \\
(33)\end{array}$ & $\begin{array}{l}1412.3 \\
1455.5 \\
1581.8\end{array}$ & $\begin{array}{l}(98) \\
(92) \\
(65)\end{array}$ & 1909.3 & (3256) & $\begin{array}{l}2750.5(77) \\
2825.1(69) \\
3043.0(53)\end{array}$ & $3573.5(2670)$ \\
\hline Tobacco & $\begin{array}{l}\mathbf{A} \\
\mathbf{B} \\
\mathbf{C}\end{array}$ & $\begin{array}{l}669.0 \\
682.6 \\
703.6\end{array}$ & $\begin{array}{l}(8) \\
(7) \\
(5)\end{array}$ & - & & $\begin{array}{l}727.2 \\
727.2 \\
838.2\end{array}$ & $\begin{array}{l}(15) \\
(15) \\
(12)\end{array}$ & 715.0 & $(628)$ & $\begin{array}{l}1781.4(12) \\
1781.4(12) \\
1809.8(11)\end{array}$ & $1120.3(918)$ \\
\hline $\begin{array}{l}\text { Wool } \\
\text { Textiles }\end{array}$ & $\begin{array}{l}\mathbf{A} \\
\mathbf{B} \\
\mathbf{C}\end{array}$ & $\begin{array}{l}677.3 \\
821.3 \\
906.1\end{array}$ & $\begin{array}{l}(53) \\
(35) \\
(19)\end{array}$ & $\begin{array}{l}1662.8 \\
1664.8 \\
1681.3\end{array}$ & $\begin{array}{l}(59) \\
(58) \\
(48)\end{array}$ & $\begin{array}{l}1756.1 \\
1776.7 \\
1784.6\end{array}$ & $\begin{array}{l}(42) \\
(40) \\
(35)\end{array}$ & 1530.8 & (1375) & $\begin{array}{l}2086.6(23) \\
2086.6(23) \\
2120.5(20)\end{array}$ & $2143.4(1041)$ \\
\hline
\end{tabular}


Table 2

Notes and Sources: See the note to Table 1. The estimates vere calculated as the ratio of the value of gross output to the total number of equivaleat adult male workers. 
problem, and gielded roughly imilar results. The method and procedures underlying the construction of the three set of sub-samples employed in this paper are explained in the note to Table 1. The logic behind reporting three sets of estimates is to provide evidence on the Bensitivity of the results to the ascumptions made about the prevalence of part-time operators in different years. ${ }^{5}$ Although intended to gield somewhat conservative estimstes of the rates of productivity growth over time, the $\underline{B}$ set represents the "best-guess" figures, and will be the basis, unless otherwise indicated, for the results discussed below. The major implication of the estimstes reported in Tables 1 and 2 is that nominal labor productivity, whether evaluated in terms of value added or gross output, increased substantially between 1820 and 1860. All of the thirteen selected industries registered significant advances in product per equivalent worker, by each of the measures. Ten of the thirteen managed a greater than 50 percent increase in gross output per unit of labor (GQLP) between 1820 and 1860 , and eight did by the value-added gauge of labor productivity (VLP).6 The unweighted averages of the growth over the period in the value-added and grobsoutput measures of labor productivity are 73 and 102 percent respectively, whereas the weighted average increases are only slightly different, 72 and 112 percent. 7 This record of advance might not seem remarkable taken by itself, but considered together with the evidence of sharp decreaser in output prices (see Table 3), the implied gains in real labor productivity are dramatic indeed.

It is fortunate that the principal qualitative finding eems 
to be insensitive to reasonable variation in the proportions of firms truncated from the samples to deal with the problem of the inclusion of part-time firms in the data. The A estimates imply much more oubstantial productivity growth than the "best-guess" B figures, and the $C$ set suggests somewhet less progress, but all three provide evidence of an ers of mor incresses in manufacturing productivity. This general robustness can be demonstrated by computing the implied growth in labor productivity that results from an especially extreme adjustment for the problem. 8 If, for example, one accepte the $\underline{C}$ estimates for 1820 , and the $\underline{B}$ estimates for 1860 , thus aseuning that an unrealistically bigh proportion of firms in the earlier gear operated part-time and that an extraordinary decline in their prevalence occurred, weighted averages of the estimated growth in labor productivity over the thirteen industries fall from 72 to 46 for valueadded labor productivity and from 112 to 97 percent for 8ross-output labor productivity. These are not trivial alterations to the quantitative resulte, but the picture of labor productivity growtb in manufacturing that emerges from the data remain essentially unchanged. Such senoitivity analyoic suggests that although the initial truncation of establiohments for likelg part-time operations bas major effects on estimated productivity levels and growth, the influence of successive truncations declines, to the point that no plausible revision of the proportion of firms assumed to be operating part-time in 1820 could reverse the basic finding of major advances over the period. There are several troubling features of the estimates that 
should be considered in interpreting them, but theg do not seem to warrant a general rejection of the reliability of the figures. Perbaps foremost among these is the irregular pattern of advance that auber of the industries exhibit. Nominal labor productivity does not always increase continuously across the sub-periods, and even in those industries where it does, the apparent rates of growth fluctuate videly over time. Some variability sould be expected, however, since the nominal estimates are not adusted for the substantial and erratic changes in the prices of many commodities, including outputa and raw materials, that occurred during the period. Moreover, areat deal of random variation in the estimates of productivity would also be generated by the limited numbers of observations. 9 This latter problem is quite Berious for estimating the growth in productivity over the sub-periods, but would be expected to decline in significance for the study of longterm changes, because the proportion of the variation in eatimated productivity due to substantive or actual movements in productivity should increase with the length of the period under examination.

Also purzling are the sometimes large discrepancies between the estimstes computed from the firm-level information and those from aggregate data in 1850 and 1860 . The industry estimates drawn from these two sources are frequently imilar, but diverge oubstantially in some csser, particularly in 1850. One might have expected the figureb based on aggregate data to be generally lower, because of the presumed inclusion of part-time establishments in those totals. Bowever, where there are large disparities, it is typically these 
estimates which exceed those from the firm data. This might ceem to imply that the prevalence, or the production, of part-time operators was rather modest in those years. In addition, the pattern is consistent with the view that the design of the 1850 and 1860 samples served to significantly bias the productivity estimates for those years downard. 10 Accordingly, one might suppose that the aggregatebased estimates would be more representative of the actual productivity levels in the respective industries thas those compoted from firm data. Whatever the reasons for the discrepancies, the close correspondence between the estimates in 1860 means that the qualitative results on productivity growth over the entire period are not sensitive to the choice between the firm- and aggregate-based figures for that year. Altbough the ceries of current-dollar eatimates are useful in roughly gauging the long-term trends in labor productivity, they are not nearly as informative as would be series expressed in constant dollars. Accordingly, variety of price indexes have been assembled to construct estimstes of real productivity from current-dollar values, and are reported in Iable 3. Heasures of the changes in the prices of the outputs and of the raw material. for each of the thirteen industries would of course be preferred for the calculation of the constant-dollar estimetes. This gosl could not be achieved, but a wideranging survey of available price series for the period yielded industry-specific indexes for the outputs of all thirteen industries, and for the raw materials of nine. 11 The Warren and Pearoon Price Index (henceforth referred to as the WPI) was employed as the index for 
TABLE 3

Price Indexes, 1820 to 1860

\begin{tabular}{|c|c|c|c|c|c|}
\hline & & 1820 & 1832 & 1850 & 1860 \\
\hline $\begin{array}{r}\text { Gederal } \\
\text { Consumer } \\
\text { Wbolesale }\end{array}$ & $\begin{array}{l}\text { Indexes } \\
\text { Index } \\
\text { Index }\end{array}$ & $\begin{array}{l}156 \\
114\end{array}$ & $\begin{array}{r}119 \\
99\end{array}$ & $\begin{array}{l}93 \\
88\end{array}$ & $\begin{array}{l}100 \\
102\end{array}$ \\
\hline$\frac{\text { Industry }}{\text { Boots/Shoes }}$ & $\underset{\mathbf{R H}}{\mathbf{R}}$ & $\begin{array}{l}166 \\
113 \\
140\end{array}$ & $\begin{array}{l}155 \\
124 \\
135\end{array}$ & $\begin{array}{r}111 \\
88 \\
103\end{array}$ & $\begin{array}{l}100 \\
113 \\
105\end{array}$ \\
\hline $\begin{array}{l}\text { Coacbes/ } \\
\text { Barnesses }\end{array}$ & $\underset{R}{Q Q}$ & $\begin{array}{l}178 \\
137 \\
150\end{array}$ & $\begin{array}{l}141 \\
119 \\
128\end{array}$ & $\begin{array}{r}95 \\
106 \\
109\end{array}$ & $\begin{array}{l}100 \\
102 \\
102\end{array}$ \\
\hline $\begin{array}{l}\text { Cottod } \\
\text { Textiles }\end{array}$ & $\underset{\mathbf{R}}{\mathbf{Q}}$ & $\begin{array}{l}179 \\
155 \\
160\end{array}$ & $\begin{array}{r}115 \\
88 \\
130\end{array}$ & $\begin{array}{r}78 \\
69 \\
112\end{array}$ & $\begin{array}{r}98 \\
110 \\
103\end{array}$ \\
\hline $\begin{array}{l}\text { Furaiture/ } \\
\text { Woodvork }\end{array}$ & $\underset{\mathbf{R M}}{\mathbf{Q}}$ & $\begin{array}{l}200 \\
111 \\
151\end{array}$ & $\begin{array}{l}149 \\
102 \\
126\end{array}$ & $\begin{array}{l}111 \\
121 \\
115\end{array}$ & $\begin{array}{r}100 \\
98 \\
100\end{array}$ \\
\hline Gias: & $\begin{array}{r}Q \\
\text { RM } \\
\mathbf{X}\end{array}$ & $\begin{array}{l}190 \\
114 \\
149\end{array}$ & $\begin{array}{r}109 \\
99 \\
115\end{array}$ & $\begin{array}{l}81 \\
88 \\
99\end{array}$ & $\begin{array}{l}100 \\
102 \\
101\end{array}$ \\
\hline Eats & $\underset{R M}{Q}$ & $\begin{array}{l}166 \\
114 \\
142\end{array}$ & $\begin{array}{r}155 \\
99 \\
127\end{array}$ & $\begin{array}{r}111 \\
88 \\
105\end{array}$ & $\begin{array}{l}105 \\
102 \\
103\end{array}$ \\
\hline Irod & $\begin{array}{r}Q \\
\text { RM } \\
\mathbf{R}\end{array}$ & $\begin{array}{l}171 \\
128 \\
159\end{array}$ & $\begin{array}{l}145 \\
111 \\
137\end{array}$ & $\begin{array}{r}113 \\
99 \\
118\end{array}$ & $\begin{array}{l}100 \\
102 \\
103\end{array}$ \\
\hline Liquor & $\underset{\mathbf{R}}{Q}$ & $\begin{array}{r}96 \\
57 \\
124\end{array}$ & $\overline{-}$ & $\begin{array}{r}91 \\
83 \\
106\end{array}$ & $\begin{array}{r}104 \\
96 \\
102\end{array}$ \\
\hline $\begin{array}{l}\text { Flourl } \\
\text { Grist Mille }\end{array}$ & $\underset{\mathbf{R}}{\mathbf{Q}}$ & $\begin{array}{r}91 \\
57 \\
142\end{array}$ & $\overline{-}$ & $\begin{array}{r}87 \\
83 \\
115\end{array}$ & $\begin{array}{r}98 \\
96 \\
102\end{array}$ \\
\hline Paper & $\begin{array}{r}Q \\
R Y \\
R\end{array}$ & $\begin{array}{l}319 \\
179 \\
164\end{array}$ & $\begin{array}{l}244 \\
115 \\
136\end{array}$ & $\begin{array}{r}125 \\
78 \\
111\end{array}$ & $\begin{array}{r}104 \\
98 \\
101\end{array}$ \\
\hline Tanding & $\begin{array}{r}Q \\
R M \\
R\end{array}$ & $\begin{array}{r}90 \\
65 \\
104\end{array}$ & $\begin{array}{r}99 \\
72 \\
101\end{array}$ & $\begin{array}{l}70 \\
51 \\
81\end{array}$ & $\begin{array}{l}113 \\
113 \\
108\end{array}$ \\
\hline Tobacco & $\begin{array}{r}Q \\
R M \\
R\end{array}$ & $\begin{array}{l}138 \\
138 \\
140\end{array}$ & $\begin{array}{l}69 \\
69 \\
81\end{array}$ & $\begin{array}{l}100 \\
100 \\
103\end{array}$ & $\begin{array}{l}127 \\
127 \\
122\end{array}$ \\
\hline $\begin{array}{l}\text { Wool } \\
\text { Textiles }\end{array}$ & $\begin{array}{r}Q \\
R+ \\
R\end{array}$ & $\begin{array}{r}161 \\
95 \\
144\end{array}$ & $\begin{array}{r}138 \\
74 \\
124\end{array}$ & $\begin{array}{r}133 \\
80 \\
114\end{array}$ & $\begin{array}{l}102 \\
104 \\
102\end{array}$ \\
\hline $\begin{array}{c}\text { Pitol } \\
\text { Macbinery } \\
\text { Structures }\end{array}$ & e Inde & $\begin{array}{l}183 \\
136\end{array}$ & $\begin{array}{l}159 \\
118\end{array}$ & $\begin{array}{l}138 \\
107 \\
\end{array}$ & $\begin{array}{l}107 \\
100 \\
\end{array}$ \\
\hline
\end{tabular}


Table 3

Notes and Sources: Corresponding to the productivity estimates, the price indexes reported for 1832,1850 , and 1860 actually refer to the price levels in 1831, 1849, and 1859. The price indexes, however, are expressed relative to an 1860 standard of 100 . The industry-specific capital price indexes vere constructed a veighted average of the price indexes for "structures" and "machinery", as well as of the industry-specific indexes for output and raw materials. The veights were obtained from firm level data on the composition of the total capital investment contained in the Mclane Report or, when there vere insufficient observations from 1832, from aggregate information contained in the report of the 1890 Census of Manufactures. See Sokoloff (1984a) and D. S Census Office (1895). The "structures" and "machinery" indexes were weighted by the shares of the total capital investment that they accounted for in the respective industries. The remaining proportion of the capital investment vas assumed to consist entirely of inventories, which vere divided equally between output and raw materials. Bence, the latter two indexes received half of the weight for inventories in constructing each industry's capital price series.

General Output: Consumer and Wholessle Price Indexes (CPI and WPI henceforth) from U. S. Bureau of the Census (1975, B-135 and E-52). 
Boots/Shoes: Output price index for "shoes" from Brady (1966). Interpolation was based on the WPI (as were all interpolations of price indexes drawn from Brady). The index for raw materials was constructed frow the 1850 and 1860 firm data, and from U. S. Butesu of the Census (1975, E-55).

Coaches/Barnesses: Output index constructed from that for "carriages, buggies, and wagons" in Brady (1966), and from the 1850 and $1860 \mathrm{firm}$ data. The index for raw material also consist of segment obtained from these data, epliced into the WPI.

Cotton Textiles: Both the output and raw materials inderea are from D. S. Bureau of the Census (1975, E-128 and E-126).

Furniture/Woodwork: The output index is that for "furniture" from Brady (1966), and the raw materials index is from 0 . S. Bureau of the Census (1975, E-59), and the 1850 and 1860 firm data.

Glass: The output index is that for "window glass" from Brady (1964). The WPI serves as the index for raw materials.

Hats: The output index is that for "ben" bats" from Bredy (1964) The WPI serves as the index for raw materiala. 
Iron: The output index was constructed from several price series contained in Cole (1938). The raw materials index is the WPI, with a segment estimated from the 1850 and 1860 firm data spliced in.

Liquors: Botb inderes are from 0 . S. Bureau of the Census (1975, E-62 and $E-123)$.

Mills: Both indexes are from D. S. Bureau of the Census (1975, E-124 and E-123).

Paper: The output price index is that for "writing paper" from Brady (1966). The index for raw material is from 0 . S. Bureau of the Census (1975, E-128).

Tanning: The same price index serves here as the basis for both the output and raw materials indexes, D. S. Bureau of the Census (1975, 8-55). The two indexes differ slightly, however, in that the segments between 1850 and 1860 were obtained from the firm data for those years.

Tobacco: A price index for "tobacco" was conatructed from several series appearing in Cole (1938). This index was utilized for both outputs and raw materials. 
Wool Textiles: The output index is for "woolen vorsted goods" from Brady (1966). The index for raw materials vas constructed from information in Cole (1938).

Capital Component Price Indexes: The indexes for structures and machinery are for "factories, office buildings" and "machineshop products" respectively. Botb are drawn from Brady (1966). 
the prices of raw materials in the remaining four industries. In cases where there was reason to doubt the representativeness of an index, and where the procedure was fessible, the cbange in price between 1850 and 1860 vas estimated from the information in the omples from those years, and patched into the original series. 12

In addition to these price indexes for outputs and raw materials, Table 3 also presents industry-specific estimates of the price of capital. These indexes of the price of capital will be utilized in the calculations of total factor productivity treated below, and were computed as weighted averages of the indexes for structures, machinery, outputs, and raw materials. The veights vary across industries, and vere obtained from industry-specific proportions of capital invested in structures and land, machinery and tools, and inventories. Inventories were assumed to bave been composed of equal amount of outputs and of raw materials.

Perhaps the most striking general pattern that emerges from an examination of Table 3 is that the prices of outputs declined ignificanty relative to those of raw materials and capital between 1820 and 1860 . In 11 of the thirteen industries but tobacco, where the ame series was adopted for botb outputs and raw materialo, the index for output prices fell relative to that for raw material ; the index declined relative to that for capital in ten of the thirteen. Since it is also clear that real wages rose substantially over the period, one can infer, by duality, that total factor productivity must have increased (Sokoloff, 1983). 
Indexes of real value added and real gross output per equivalent worker have been constructed for the thirteen industries by applying the output price series to the conversion of the current-dollar labor productivity estimates to units of constant dollars. These indexes, which are presented in Tables 4 and 5 respectively, indicate that all of the industries realized major advances in real labor productivity, by either measure, between 1820 and 1860 . Weighted averages of the records of the industries yield, taking the estimates based on eggregate data as the standard for 1860 , increases of 166 percent in value added per equivalent worker and 198 percent by the alternative gauge. Only very few failed to register gains of 100 percent. It is interesting to note that in most industries the progress in grose output per equivalent worker significantly exceeded that in value added per equivalent worker. This feature of the results presumably reflects a rapid growth in the amounts of raw materials processed per unit of labor during the period.

As for the reliability of these labor productivity estimates, it must be admitted that even after their conversion to constant dollars, there remsin many anomalies where the productivity growth indicated for an industry over a sub-period is eitber implausibly high or low. These cases generally involve rather short spans of time, but not always. Many of them might be attributed to noise in the point estimates generated by a pacity of observations, inappropriate or inaccurate price indexes, rapid changes in the factor proportions utilized, varying degrees or types of ample selection bias over the 
TABLE 4

Indez of Real Value Added Per Equivalent Worker in Selected Manufacturing Induaties: 1820 to 1860

\begin{tabular}{|c|c|c|c|c|c|c|c|}
\hline & & 1820 & 1832 & $\begin{array}{l}1850 \\
(f i \operatorname{sms})\end{array}$ & $\begin{array}{l}1850 \\
(188 .)\end{array}$ & $\begin{array}{c}1860 \\
(f i 25)\end{array}$ & $\begin{array}{c}1860 \\
(888 .)\end{array}$ \\
\hline Boots/Shoes & $\begin{array}{l}A \\
B \\
C\end{array}$ & $\begin{array}{l}100 \\
100 \\
100\end{array}$ & $\begin{array}{l}- \\
-\end{array}$ & $\begin{array}{l}154 \\
135 \\
131\end{array}$ & $\begin{array}{l}165 \\
142 \\
130\end{array}$ & $\begin{array}{l}259 \\
224 \\
216\end{array}$ & $\begin{array}{l}254 \\
217 \\
200\end{array}$ \\
\hline $\begin{array}{l}\text { Coaches/ } \\
\text { Barnesseg }\end{array}$ & $\begin{array}{l}A \\
B \\
C\end{array}$ & $\begin{array}{l}100 \\
100 \\
100\end{array}$ & $\begin{array}{l}88 \\
93 \\
93\end{array}$ & $\begin{array}{l}154 \\
176 \\
173\end{array}$ & $\begin{array}{l}172 \\
166 \\
162\end{array}$ & $\begin{array}{l}260 \\
253 \\
229\end{array}$ & $\begin{array}{l}225 \\
218 \\
213\end{array}$ \\
\hline $\begin{array}{l}\text { Cotton } \\
\text { Textiles }\end{array}$ & $\begin{array}{l}A \\
B \\
C\end{array}$ & $\begin{array}{l}100 \\
100 \\
100\end{array}$ & $\begin{array}{l}222 \\
201 \\
175\end{array}$ & $\begin{array}{l}210 \\
192 \\
196\end{array}$ & $\begin{array}{l}299 \\
270 \\
231\end{array}$ & $\begin{array}{l}256 \\
231 \\
247\end{array}$ & $\begin{array}{l}400 \\
361 \\
308\end{array}$ \\
\hline $\begin{array}{l}\text { Furniturel } \\
\text { Woodvork }\end{array}$ & $\begin{array}{l}\mathbf{A} \\
\mathbf{B} \\
\mathbf{C}\end{array}$ & $\begin{array}{l}100 \\
100 \\
100\end{array}$ & $\begin{array}{l}122 \\
113 \\
104\end{array}$ & $\begin{array}{l}174 \\
175 \\
155\end{array}$ & $\begin{array}{l}236 \\
215 \\
188\end{array}$ & $\begin{array}{l}337 \\
3 \overline{2} 1 \\
291\end{array}$ & $\begin{array}{l}341 \\
311 \\
272\end{array}$ \\
\hline GI:85 & $\begin{array}{l}A \\
B \\
C\end{array}$ & $\begin{array}{l}100 \\
100 \\
100\end{array}$ & $\begin{array}{l}274 \\
274 \\
253\end{array}$ & $\begin{array}{l}- \\
-\end{array}$ & $\begin{array}{l}285 \\
285 \\
268\end{array}$ & $\begin{array}{l}- \\
-\end{array}$ & $\begin{array}{l}265 \\
265 \\
249\end{array}$ \\
\hline Bat $B$ & $\begin{array}{l}\mathbf{A} \\
\mathbf{B} \\
\mathbf{C}\end{array}$ & $\begin{array}{l}100 \\
100 \\
100\end{array}$ & $\begin{array}{l}139 \\
119 \\
145\end{array}$ & $\begin{array}{l}212 \\
184 \\
228\end{array}$ & $\begin{array}{l}227 \\
195 \\
229\end{array}$ & $\begin{array}{l}299 \\
257 \\
297\end{array}$ & $\begin{array}{l}306 \\
263 \\
309\end{array}$ \\
\hline Iron & $\begin{array}{l}\mathrm{A} \\
\mathrm{B} \\
\mathrm{C}\end{array}$ & $\begin{array}{l}100 \\
100 \\
100\end{array}$ & - & $\begin{array}{l}142 \\
115 \\
122\end{array}$ & $\begin{array}{l}203 \\
122 \\
120\end{array}$ & $\begin{array}{l}277 \\
180 \\
203\end{array}$ & $\begin{array}{l}318 \\
190 \\
188\end{array}$ \\
\hline Iiquors & $\begin{array}{l}\mathbf{A} \\
\mathbf{B} \\
\mathbf{C}\end{array}$ & $\begin{array}{l}100 \\
100 \\
100\end{array}$ & $\begin{array}{l}- \\
-\end{array}$ & $\begin{array}{l}127 \\
115 \\
126\end{array}$ & $\begin{array}{l}209 \\
173 \\
166\end{array}$ & $\begin{array}{l}220 \\
193 \\
210\end{array}$ & $\begin{array}{l}256 \\
212 \\
203\end{array}$ \\
\hline $\begin{array}{l}\text { Flour/ } \\
\text { Grist Hillo }\end{array}$ & $\begin{array}{l}\Delta \\
B \\
C\end{array}$ & $\begin{array}{l}100 \\
100 \\
100\end{array}$ & $\begin{array}{l}- \\
-\end{array}$ & $\begin{array}{l}125 \\
101 \\
110\end{array}$ & $\begin{array}{l}163 \\
127 \\
113\end{array}$ & $\begin{array}{l}177 \\
148 \\
153\end{array}$ & $\begin{array}{l}190 \\
149 \\
132\end{array}$ \\
\hline Paper & $\begin{array}{l}\mathbf{A} \\
\mathrm{B} \\
\mathrm{C}\end{array}$ & $\begin{array}{l}100 \\
100 \\
100\end{array}$ & $\begin{array}{l}179 \\
176 \\
181\end{array}$ & $\begin{array}{r}588 \\
580 \\
521\end{array}$ & $\begin{array}{l}547 \\
539 \\
523\end{array}$ & $\begin{array}{l}509 \\
511 \\
562\end{array}$ & $\begin{array}{l}813 \\
801 \\
777\end{array}$ \\
\hline Tanding & $\begin{array}{l}A \\
B \\
C\end{array}$ & $\begin{array}{l}100 \\
100 \\
100\end{array}$ & $\begin{array}{r}160 \\
128 \\
99\end{array}$ & $\begin{array}{l}198 \\
163 \\
145\end{array}$ & $\begin{array}{l}295 \\
234 \\
196\end{array}$ & $\begin{array}{l}193 \\
157 \\
143\end{array}$ & $\begin{array}{l}248 \\
196 \\
165\end{array}$ \\
\hline Tobacco & $\begin{array}{l}\mathbf{A} \\
\mathbf{B} \\
\mathbf{C}\end{array}$ & $\begin{array}{l}100 \\
100 \\
100\end{array}$ & - & $\begin{array}{l}141 \\
135 \\
148\end{array}$ & $\begin{array}{r}108 \\
104 \\
98\end{array}$ & $\begin{array}{l}261 \\
250 \\
240\end{array}$ & $\begin{array}{l}237 \\
227 \\
215\end{array}$ \\
\hline $\begin{array}{l}\text { Hool } \\
\text { Textiles }\end{array}$ & $\begin{array}{l}\text { A } \\
\text { B } \\
\text { C }\end{array}$ & $\begin{array}{l}100 \\
100 \\
100\end{array}$ & $\begin{array}{l}203 \\
163 \\
147\end{array}$ & $\begin{array}{l}237 \\
192 \\
173\end{array}$ & $\begin{array}{l}183 \\
146 \\
132\end{array}$ & $\begin{array}{l}368 \\
295 \\
256\end{array}$ & $\begin{array}{l}359 \\
288 \\
259\end{array}$ \\
\hline $\begin{array}{l}\text { Average } \\
\text { Weighted } \\
\text { Onveighted }\end{array}$ & $\begin{array}{l}\mathbf{B} \\
\mathbf{B}\end{array}$ & $\begin{array}{l}100 \\
100\end{array}$ & $\begin{array}{l}{[129]} \\
{[142]}\end{array}$ & $\begin{array}{l}{[169]} \\
{[189]}\end{array}$ & $\begin{array}{l}194 \\
209\end{array}$ & $\begin{array}{l}{[229]} \\
{[239]}\end{array}$ & $\begin{array}{l}266 \\
284\end{array}$ \\
\hline
\end{tabular}


Table 4

Notes snd Sources: See the notes to Tables 1 and 3 . The estimates of value added per equivalent vorker presented in Table 1 vere converted to constant dollars by enploying the price indexes reported in Table 3 , and then normalized relative to base of 100 representing the respective industry ${ }^{\circ}$ level in 1820 . The veights employed in computing the veighted averages are equivalent to the industry shares of the value added produced in the northeastern otates in 1850 , and vere calculated from information contained in 0 . S. Census office (1858). The weights were normalized 00 that their sum was equal to one whenever there vere missing values. Averages based on fewer than thirteen industries (affected by missing values) are reported witbin brackets. 
TABLE 5

Index of Real Grose Output per Equivalent Worker in Selected Hanufacturing Induatries: 1820 to 1860

\begin{tabular}{|c|c|c|c|c|c|c|c|}
\hline & & 1820 & 1832 & $\begin{array}{l}1850 \\
(f \text { irmo })\end{array}$ & $\begin{array}{c}1850 \\
(188 .)\end{array}$ & $\begin{array}{l}1860 \\
(\mathrm{f} \text { irma })\end{array}$ & $\begin{array}{c}1860 \\
(488 .)\end{array}$ \\
\hline Boots/Shoes & $\begin{array}{l}\mathbf{A} \\
\mathbf{B} \\
\mathbf{C}\end{array}$ & $\begin{array}{l}100 \\
100 \\
100\end{array}$ & - & $\begin{array}{l}161 \\
145 \\
149\end{array}$ & $\begin{array}{l}163 \\
145 \\
142\end{array}$ & $\begin{array}{l}290 \\
260 \\
263\end{array}$ & $\begin{array}{l}258 \\
230 \\
224\end{array}$ \\
\hline $\begin{array}{l}\text { Coacbes/ } \\
\text { Barnesies }\end{array}$ & $\begin{array}{l}\mathbf{A} \\
\mathbf{B} \\
\mathrm{C}\end{array}$ & $\begin{array}{l}100 \\
100 \\
100\end{array}$ & $\begin{array}{l}83 \\
86 \\
85\end{array}$ & $\begin{array}{l}164 \\
187 \\
189\end{array}$ & $\begin{array}{l}164 \\
158 \\
155\end{array}$ & $\begin{array}{l}240 \\
233 \\
218\end{array}$ & $\begin{array}{l}201 \\
194 \\
190\end{array}$ \\
\hline $\begin{array}{l}\text { Cotton } \\
\text { Textiles }\end{array}$ & $\begin{array}{l}\mathbf{A} \\
\mathbf{B} \\
\mathbf{C}\end{array}$ & $\begin{array}{l}100 \\
100 \\
100\end{array}$ & $\begin{array}{l}216 \\
200 \\
182\end{array}$ & $\begin{array}{l}359 \\
336 \\
301\end{array}$ & $\begin{array}{l}369 \\
341 \\
309\end{array}$ & $\begin{array}{l}288 \\
267 \\
361\end{array}$ & $\begin{array}{l}409 \\
379 \\
343\end{array}$ \\
\hline $\begin{array}{l}\text { Puraiture/ } \\
\text { Hoodwork }\end{array}$ & $\begin{array}{l}\mathbf{A} \\
\mathbf{B} \\
\mathrm{C}\end{array}$ & $\begin{array}{l}100 \\
100 \\
100\end{array}$ & $\begin{array}{l}144 \\
138 \\
127\end{array}$ & $\begin{array}{l}207 \\
201 \\
181\end{array}$ & $\begin{array}{l}238 \\
225 \\
197\end{array}$ & $\begin{array}{l}325 \\
320 \\
288\end{array}$ & $\begin{array}{l}327 \\
309 \\
270\end{array}$ \\
\hline Glase & $\begin{array}{l}\mathbf{A} \\
\mathbf{B} \\
\mathbf{C}\end{array}$ & $\begin{array}{l}100 \\
100 \\
100\end{array}$ & $\begin{array}{l}335 \\
335 \\
312\end{array}$ & - & $\begin{array}{l}305 \\
305 \\
284\end{array}$ & $\begin{array}{l}- \\
-\end{array}$ & $\begin{array}{l}290 \\
290 \\
269\end{array}$ \\
\hline Bete & $\begin{array}{l}\mathbf{A} \\
\mathbf{B} \\
\mathbf{C}\end{array}$ & $\begin{array}{l}100 \\
100 \\
100\end{array}$ & $\begin{array}{l}138 \\
122 \\
139\end{array}$ & $\begin{array}{l}250 \\
223 \\
252\end{array}$ & $\begin{array}{l}240 \\
213 \\
234\end{array}$ & $\begin{array}{l}371 \\
328 \\
362\end{array}$ & $\begin{array}{l}319 \\
282 \\
311\end{array}$ \\
\hline Iron & $\begin{array}{l}\mathbf{A} \\
\mathrm{B} \\
\mathrm{C}\end{array}$ & $\begin{array}{l}100 \\
100 \\
100\end{array}$ & $\begin{array}{l}- \\
-\end{array}$ & $\begin{array}{r}148 \\
105 \\
99\end{array}$ & $\begin{array}{l}205 \\
124 \\
116\end{array}$ & $\begin{array}{l}329 \\
218 \\
228\end{array}$ & $\begin{array}{l}321 \\
195 \\
181\end{array}$ \\
\hline Liquors & $\begin{array}{l}\mathbf{A} \\
\mathbf{B} \\
\mathbf{C}\end{array}$ & $\begin{array}{l}100 \\
100 \\
100\end{array}$ & $=$ & $\begin{array}{l}99 \\
90 \\
98\end{array}$ & $\begin{array}{l}227 \\
187 \\
180\end{array}$ & $\begin{array}{l}253 \\
221 \\
231\end{array}$ & $\begin{array}{l}252 \\
209 \\
201\end{array}$ \\
\hline $\begin{array}{l}\text { Flourl } \\
\text { Griet Mill. }\end{array}$ & $\begin{array}{l}\mathbf{A} \\
\mathrm{B} \\
\mathrm{C}\end{array}$ & $\begin{array}{l}100 \\
100 \\
100\end{array}$ & $\begin{array}{l}- \\
-\end{array}$ & $\begin{array}{l}209 \\
166 \\
189\end{array}$ & $\begin{array}{l}263 \\
202 \\
193\end{array}$ & $\begin{array}{l}274 \\
224 \\
231\end{array}$ & $\begin{array}{l}293 \\
225 \\
216\end{array}$ \\
\hline Paper & $\begin{array}{l}\mathbf{A} \\
\mathbf{C}\end{array}$ & $\begin{array}{l}100 \\
100 \\
100\end{array}$ & $\begin{array}{l}278 \\
275 \\
280\end{array}$ & $\begin{array}{l}823 \\
816 \\
722\end{array}$ & $\begin{array}{l}789 \\
783 \\
764\end{array}$ & $\begin{array}{l}744 \\
751 \\
833\end{array}$ & $\begin{array}{l}1050 \\
1042 \\
1016\end{array}$ \\
\hline Teoning & $\begin{array}{l}4 \\
\mathrm{C}\end{array}$ & $\begin{array}{l}100 \\
100 \\
100\end{array}$ & $\begin{array}{l}164 \\
136 \\
108\end{array}$ & $\begin{array}{l}213 \\
180 \\
167\end{array}$ & $\begin{array}{l}288 \\
237 \\
201\end{array}$ & $\begin{array}{l}257 \\
217 \\
198\end{array}$ & $\begin{array}{l}333 \\
274 \\
233\end{array}$ \\
\hline Tobacco & $\begin{array}{l}\mathbf{A} \\
\mathrm{B} \\
\mathrm{C}\end{array}$ & $\begin{array}{l}100 \\
100 \\
100\end{array}$ & $\begin{array}{l}- \\
-\end{array}$ & $\begin{array}{l}150 \\
147 \\
164\end{array}$ & $\begin{array}{l}147 \\
145 \\
140\end{array}$ & $\begin{array}{l}289 \\
284 \\
280\end{array}$ & $\begin{array}{l}182 \\
178 \\
173\end{array}$ \\
\hline $\begin{array}{l}\text { Wool } \\
\text { Textiles }\end{array}$ & $\begin{array}{l}\mathrm{A} \\
\mathrm{B} \\
\mathrm{C}\end{array}$ & $\begin{array}{l}100 \\
100 \\
100\end{array}$ & $\begin{array}{l}286 \\
236 \\
216\end{array}$ & $\begin{array}{l}314 \\
262 \\
238\end{array}$ & $\begin{array}{l}274 \\
226 \\
205\end{array}$ & $\begin{array}{l}486 \\
401 \\
369\end{array}$ & $\begin{array}{l}500 \\
412 \\
373\end{array}$ \\
\hline $\begin{array}{l}\text { Average } \\
\text { Weighted } \\
\text { Unweighted }\end{array}$ & $\begin{array}{l}\mathbf{B} \\
\mathbf{B}\end{array}$ & $\begin{array}{l}100 \\
100\end{array}$ & $\begin{array}{l}{[151]} \\
{[164]}\end{array}$ & $\begin{array}{l}\{215] \\
{[236]}\end{array}$ & $\begin{array}{l}230 \\
253\end{array}$ & $\begin{array}{l}{[275]} \\
{[298]}\end{array}$ & $\begin{array}{l}298 \\
325\end{array}$ \\
\hline
\end{tabular}


Table 5

Notes and Sources: See the notes to Tables 2 and 3 . The eatimates of gross output per equivalent worker in current dollars presented in Table 2 were converted to constant dollars by employing the price indexes reported in Table 3, and then normalized relative to a base of 100 representing the respective industry" level in 1820. The weights emploged in computing the veighted averages are equivalent to the industry hares of gross output produced in the nortbeastern states in 1850, and were calculated from information contained in 0 . S. Census Office (1858). The weight vere normalized so that their um was equal to one whenever there vere wissing values. Averages based on fewer than thirteen industries (affected by missing values) are reported witbin brackets. 
years included, or cyclical effects, but their number is nevertbeless unsettling. It is, bowever, reassuring to note that the frequency and magnitude of Buch strange results are greatly reduced in the series of total factor productivity estimates discussed below. 13 The industry with the most puzzling record is paper, which appess, by both messures of labor productivity, to have realized astonishingly bigh rates of advance, particularly after 1832. Although abstantial progress would be expected, because of the dramatic increases in the utilization of Iaw materials and capital per unit of labor over the period, the estimated gains are probably too large to be believed. Given that this qualitative result is not sensitive to the choice between the firmlevel and aggregate estimates, the problem may atem from the output price inder employed. 14 Anomalies in the productivity series for boots/shoes, tanning, and tobacco are also associated with suspicious movements in the relevant price indexes. 15

The per anum growth rates of labor productivity presented in Table 6 vere computed from the $\underline{B}$ sets of indexes in Table 4 and 5 . Rates of advance are reported for the entire period from 1820 to 1860 , as well as for several ub-periods. The estimates indicate that labor productivity increased rapidly in virtually all industries, ranging from 1.0 and 2.1 percent per annum for VLP and CQLP respectively in flour/grist mills to $4.3-5.5$ and 5.3-6.2 percent in paper. Weighted averages of the performance of the thirteen industries gield estimated ranges of $2.0-2.4$ percent and $2.5-2.7$ percent for the rates of growtb of the two mesever of 2abor productivity. These figures are 
TABLE 6

Growth Rates of Labor Productivity

in Selected Manufacturing Industries: 1820 to 1860

\begin{tabular}{|c|c|c|c|c|c|}
\hline & & $\frac{1820-1832}{7}$ & $\begin{array}{c}1820-1850 \\
7\end{array}$ & $\begin{array}{c}1850-1860 \\
7\end{array}$ & $\begin{array}{c}1820-1860 \\
z\end{array}$ \\
\hline Boots/Stoes & $\begin{array}{r}\text { VLP } \\
\text { CQLP }\end{array}$ & - & $\begin{array}{l}1.0-1.2 \\
1.3-1.3\end{array}$ & $\begin{array}{l}4.4-5.2 \\
4.7-6.0\end{array}$ & $\begin{array}{l}2.0-2.1 \\
2.2-2.5\end{array}$ \\
\hline $\begin{array}{l}\text { Coacbes } j \\
\text { Barnessed }\end{array}$ & $\begin{array}{l}\text { VLP } \\
\text { CQLP }\end{array}$ & $\begin{array}{l}-0.7 \\
-1.4\end{array}$ & $\begin{array}{l}1.8-2.0 \\
1.6-2.2\end{array}$ & $\begin{array}{l}2.7-3.7 \\
2.1-2.2\end{array}$ & $\begin{array}{l}2.0-2.4 \\
1.7-2.2\end{array}$ \\
\hline $\begin{array}{l}\text { Cotton } \\
\text { Textiles }\end{array}$ & $\begin{array}{r}\text { VLP } \\
\text { CQLP }\end{array}$ & $\begin{array}{l}6.6 \\
6.5\end{array}$ & $\begin{array}{l}2.3-3.5 \\
4 \cdot 3-4.3\end{array}$ & $\begin{array}{r}1.9-2.9 \\
-2.3-1.0\end{array}$ & $\begin{array}{l}2.2-3.3 \\
2.5-3.5\end{array}$ \\
\hline $\begin{array}{l}\text { Furaiture/ } \\
\text { Hoodvork }\end{array}$ & $\begin{array}{l}\text { VIP } \\
\text { CQLP }\end{array}$ & $\begin{array}{l}1.1 \\
3.0\end{array}$ & $\begin{array}{l}1.9-2.7 \\
2.4-2.8\end{array}$ & $\begin{array}{l}3.8-6.2 \\
3.2-4.8\end{array}$ & $\begin{array}{l}2.9-3.0 \\
2.9-3.0\end{array}$ \\
\hline Glase & $\begin{array}{r}\text { VLP } \\
\text { CQLP }\end{array}$ & $\begin{array}{r}9.6 \\
11.6\end{array}$ & $\begin{array}{l}3.7 \\
3.9\end{array}$ & $\begin{array}{l}-0.7 \\
-0.5\end{array}$ & $\begin{array}{l}2.5 \\
2.8\end{array}$ \\
\hline gets & $\begin{array}{r}\text { VLP } \\
\text { CQLP }\end{array}$ & $\begin{array}{l}1.6 \\
1.9\end{array}$ & $\begin{array}{l}2.1-2.3 \\
2.6-2.8\end{array}$ & $\begin{array}{l}3.0-3.4 \\
2.9-4.0\end{array}$ & $\begin{array}{l}2.4-2.5 \\
2.7-3.1\end{array}$ \\
\hline Iron & $\begin{array}{r}\text { VLP } \\
\text { GQLP }\end{array}$ & - & $\begin{array}{l}0.5-0.7 \\
0.2-0.8\end{array}$ & $\begin{array}{l}4.6-4.6 \\
4.6-7.5\end{array}$ & $\begin{array}{l}1.5-1.7 \\
1.7-2.0\end{array}$ \\
\hline Liquor: & $\begin{array}{r}\text { VLP } \\
\text { CQLP }\end{array}$ & - & $\begin{array}{r}0.5-1.9 \\
-0.4-2.2\end{array}$ & $\begin{array}{l}2.0-5.3 \\
1.1-9.4\end{array}$ & $\begin{array}{l}1.7-1.9 \\
1.9-2.1\end{array}$ \\
\hline $\begin{array}{l}\text { Plour/ } \\
\text { Grist Millo }\end{array}$ & $\begin{array}{r}\text { VLP } \\
\text { CQLP }\end{array}$ & - & $\begin{array}{l}0.1-0.8 \\
1.8-2.5\end{array}$ & $\begin{array}{l}1.6-3.8 \\
1.1-3.0\end{array}$ & $\begin{array}{l}1.0-1.0 \\
2.1-2.1\end{array}$ \\
\hline Paper & $\begin{array}{l}\text { VLP } \\
\text { CQLP }\end{array}$ & $\begin{array}{l}5.3 \\
9.7\end{array}$ & $\begin{array}{l}6.0-6.2 \\
7.4-7.5\end{array}$ & $\begin{array}{l}-1.2-4.0 \\
-0.8-2.9\end{array}$ & $\begin{array}{l}4.3-5.5 \\
5.3-6.2\end{array}$ \\
\hline Tanning & $\begin{array}{l}\text { VLP } \\
\text { CQLP }\end{array}$ & $\begin{array}{l}2.2 \\
2.8\end{array}$ & $\begin{array}{l}1.7-3.0 \\
2.1-3.0\end{array}$ & $\begin{array}{r}-1.7-0.4 \\
1.5-1.8\end{array}$ & $\begin{array}{l}1.2-1.7 \\
2.0-2.6\end{array}$ \\
\hline Tobacco & $\begin{array}{r}\text { VLP } \\
\text { CQLP }\end{array}$ & - & $\begin{array}{l}0.1-1.0 \\
1.3-1.3\end{array}$ & $\begin{array}{l}6.3-8.1 \\
2.1-6.8\end{array}$ & $\begin{array}{l}2.1-2.4 \\
1.5-2.7\end{array}$ \\
\hline $\begin{array}{l}\text { Wool } \\
\text { Textiles }\end{array}$ & $\begin{array}{l}\text { VLP } \\
\text { CQLP }\end{array}$ & $\begin{array}{l}4.5 \\
8.1\end{array}$ & $\begin{array}{l}1.3-2.3 \\
2.8-3.4\end{array}$ & $\begin{array}{l}4.4-7.0 \\
4.4-6.2\end{array}$ & $\begin{array}{l}2.7-2.8 \\
3.6-3.7\end{array}$ \\
\hline $\begin{array}{l}\text { Weighted } \\
\text { Average }\end{array}$ & $\begin{array}{l}\text { VLP } \\
\text { GQLP }\end{array}$ & $\begin{array}{l}{[1.6]} \\
{[2.9]}\end{array}$ & $\begin{array}{l}{[1.6]-2.1} \\
{[2.3]-2.6}\end{array}$ & $\begin{array}{l}3.3-(3.3) \\
2.8-(3.2)\end{array}$ & $\begin{array}{l}{[2.0]-2.4} \\
{[2.5]-2.7}\end{array}$ \\
\hline
\end{tabular}


Table 6

Notes and Sources: These annual rates of growth were computed from the constant-dollar estimates of labor productivity presented in set " $B$ " of Tables 4 and 5. The VLP estimates refer to the growth of value added per equivalent worker, and the GQLP refer to the growth of gross output per equivalent worker. Ranges of estimates are often presented, reflecting the differences between tue figures derived from firm data and those based on aggregate data. See the notes to Tables 4 and 5. 
remarkable in that they are drawn from the experience of industries that togetber accounted for a large share of the entire manfacturing sector in the Northeast, and yet are substantially higher than those that other scholars concerned witb antebel lum growtb have calculated for the U. S. economy as whole. (David, 1967, 1977; Gallman, 1972a, 1972b).

Not only do these estimates of productivity growth in nortbeastern manufacturing during early industrialisation exceed what might have been expected from previous vork, but they are quite high by bistorical standards. For example, McCloskey (1981) bas computed rates of labor productivity growth for four major manfacturing industries in Britain during that country a initial phase of industrial development, 1780 to 1860 . His industry rates range from 0.9 to 2.6 percent per annum, with an umeighted average of 1.6 percent. Moreover, the figures presented here are greater than those estimated by Rendrick (1961) for the U. S. manufacturing sector between 1869 and 1957.

The otber major pattern that emerges from these estimated rates of labor productivity growth is that, on average, there appears to have been an acceleration in the pace of advance over the period. This characterization is based primarily on comparison of the record between 1820 and 1850 with that between 1850 and 1860 , and thus must be offered tentatively. An analysis focusing on the performance before and after 1832, of the eight industries for which we have estimates in that year, yields weak, if ang, evidence of acceleration. Nevertheless, the thirteen industries considered together exhibit a 
marked increase in the rate of labor productivity growth. The acceleration is particularly otriking vith the PLP measure, where a veighted average of the industries registered growth of $1.6-2.1$ percent per annum before 1850 and 3.3 percent following. On an individual industry basis, nine of the thirteen realized faster growth during the later sub-period than in the earlier one. Although, the pace of advance may indeed have quickened, it is clear that rapid progress must beve been realized a early as the $1820 \bar{s}$. While the evidence of acceleration in productivity during the initial stage of industrialization might seem to conform vell with the vork of scholars who view the diffusion of mechanization acrose the manufacturing sector during the $1840 \mathrm{~B}$ and $1850 \mathrm{~s}$ as the crucial development behind productivity growth in manfacturing, this perepective contributes little to understanding how and why the impressive advances between 1820 and 1850 vere achieved (Chandler, 1977).

Given that the utilization of sophiaticated machinery and highly capital-intensive production processes vere essentially confined to but a few industries until late in the period, the finding that a broad range of manufacturing industries enjoyed substantial gaing in productivity throughout the early nineteentb century wight tend to enbance appreciation of the importance of the changes in labor organization and other relatively modest alterationa in technique tbat ceem to bave generally been adopted sooner and more videly. Another reaction, however, would be to question the accuracy of the estimates of productivity growth. Comparisons between the rates reported bere and those computed 
for other places or eras do provide some check on the plausibility of the results, but those drawn with alternstive industry-opecific figures for the same period would be even more informative. Dnfortunately, such estimates are quite acarce, and the only prominent induatry for which they are readily available is cotton textiles. As for that industry, the rates of labor productivity growth presented here are generally lower than what other scholars have found. Davis and Stettler (1966) calculated that grose output per vorker in the entire D. S. industry increased at rates of 4.1 percent per annum between 1820 and 1860 , and of 3.4 percent between 1832 and 1860 , as compared to the 2.5-3.5 and 1.9-2.3 rates for the respective periods reported bere. Their estimates for cotton textiles in Massachusetts indicate somewhat slower rates of advance in that state; but their figure of 2.2 percent per annum growth between 1832 and 1860 , resembling the 2.0 and 2.5 rates of McGouldrick (1968) and Layer (1955) for mills in Lowell during roughly the same gears, is near the upper end of our range. Nickless"s (1979) anasis of Layer's data on three Lowell establisbments yields an even higher estimate, 3.3 percent per annum, for the period from 1836 to 1860. Hence, the evidence from the only other industry for which independent estimates are easilg obtained uggests that our figures on labor productivity growth are on the low side, as theg vere constructed to be.

A skeptic might not accept the number or relevance of the standards of comparison utilized, and continue to dispute the ertimates of the rates of advances as too high, clsiming that the resulta vere an 
artifact due to some defect in the data or in the way they vere derived. There are, indeed, several aspects of the estimation procedure that could potentially be of ouficient import to account for the findings of rapid productivity growtb across a wide epectrum of manufacturing industries, and on average, in the sector at large. Perbaps the most obvious of these is the selection of price indexes. As is clear from the indexes listed in Table 3 , there were substantial fluctuations in both absolute and relative prices over the period from 1820 to 1860. In this context, it is conceivable that some of the price inderes utilized might diverge agnificantly from the actual movement of the relevant prices, particularly since the inderes frequently pertain to only one specific product or raw material of an industry and were in several coses drawn from the UPI. Nevertheless, in order for there to be qualitatively-important upward bias in the estimates of productivity growth, the respective price inderes would have to seriously operstate the decline in output prices relative to input prices. Given the absence of ang evidence or argument that such - systematic pattern in the errors of the price indexes across industries exists, there would seem to be no basis for accepting the argument that inaccurate price indexes account for the general finding of rapid labor productivity growth.

There are several otber reasons to doubt the severity of the problems with the price indexes. The first is that when multiple price indexes were available for an industry, the most conservative of them were generally selected for use, so as to bias the estimated rates of 
productivity growth downard. Another factor that mitigates the significance of possible errors in the indexes is that the value-added figures were deflated to constant dollars with only output price indexes, instead of converting the values of gross outputs and raw materials separately. In manufacturing industries in which the prices of the raw materials consumed fell relative to the output prices, this procedure would lead the advance over time in real labor productivity to be overestimated. The evidence, however, suggests that it was the Ielative price of the output that typically declined during the period. Of the eight industries included in Iable 3 that have separate and industry-specific indexes for outputs and inputs, all experienced a decrease in the former relative to the latter. To the extent that this pattern was characteristic of the manufacturing eector, the employment of output price series to deflate the nominal value-added figures hould tend to bias estimates of productivity growth downard, not upward. Bence, the likelihood that the result of substantial advances was due to inaccurate price inderes seems even more remote. Given that there are undoubtedly some errors in the price inderes utilized, however, and that the magnitude and perbaps the direction, of the biases referred to must vary across industries, one should be cautious about comparing the relative performances reported for individual industries. Although the rates of productivity growth should be biased downard in most industries, the variability in the extent of the biases at the industry level implies that the record of any particular industry relative to another might be quite 
fragile. 16

The other feature of the construction of the estimates that the qualitative results might plaubibly be sensitive to is the method of adjustment for the inclusion of establishments operating part-time in the samples. This is a potentially important problem, because such enterprises did not generally explicitly identify themselves as such, became less prevalent in manufacturing over time, and had their measures of productivity biased dowaward from the actual levels. 17 As discussed above, the logic of the procedure adopted to deal with the dilema wased on the assuption that the lower the total factor productivity of an establisbent, the greater the likelihood it operated only a fraction of the year. Generous assessents of the prevalance of part-time operations in the various years vere made, and corresponding percentages of the least productive enterprises were dropped from the respective samples to obtain the sub-samples over which the sets of estimates were computed. The $\underline{B}$ set of estimates was intended to represent conservative "best-guess" figures, and provides the basis for the rates of growth reported in Iable 6 . If the adjustments to the samples underestimated the extent of part-time operations in 1820, or especially the decrease in their prevalence over time, then the rates of productivity growth would likely be biased upward. This is conceivably a possibility, but as an examination of the nominal figures in Table 1 and 2 indicates, the qualitative reault of rapid productivity growth, on average, in manufacturing is not sensitive to reasonable variation in the proportions of firms presumed to have been 
operating part-time and truncated frow the samples. Estimates of the advances in seversl of the industries, such as iron and taning, might be substantially affected, however, as could the relative rates of progress in some industries versus others.

There are other aspects of the estimation procedures that might be expected to gield biased results, but they are more likely to Iead to understatements of the advances in productivity than overstatements. The first concerno the manner in which value added vas computed. Each of the bodies of data employed contains reports of the value of outputs produced and the value of raw material consumed by the particular firm of industry. Palue added vas calculated in etraigbtforward fashion by deducting the value of the raw materials from the total value of output. The potential bias arises from the additional category of expenses specified by firms in the 1820 Census of Manufactures. This class of production costs was defined as "contingent expenses" and included the costs of items such as fuel, insurance, and repairs to equipment. Since none of the other urveys collected information on a similar category of expenses, "contingent expenses" vere ignored in the calculation of the value added figures for 1820 . If, however, some of the expenditures on inputs counted among "contingent expenses" in that gear were included as aw materials later, then the value added per firm would be overestimated in 1820 relative to that in other gears, and the growth in the value-added measures of productivity underestimated.

Another possible source of systematic error in the preparation 
of the productivity estimates is the method of aggregating different classes of workers into units of adult-male equivalents. Females and boys have been treated as equal, in terms of their labor input, to onehalf of an adult-male employee, with these weights having been drawn from evidence on the relative wages of the groups prevailing near the end of the period. 18 In both the 1820 Census of Manufactures and the Mclane Report of 1832, each of the three types of vorkers vere separateíy enumerated. There were only two classification of employees utilized in the 1850 and 1860 censures, bowever, males and females. For those years, the reported number of male workers in each industry was decomposed into adults and boys by assuning that the industry-specific proportions of males that were boys were the same in 1850 and 1860 as they bad been in 1820.19 Since the shares of male exployees that vere boys probably rose sowewhat over the period, a amall upward bias might be imparted by this procedure to the estimation of the labor inputs in the later, relative to the earlier, years (Goldin and Sokoloff, 1982). As a consequence, estimates of productivity in those years, and thus of its growth over time, would tend to be biased dowmard.

One wight also expect the eatimates of productivity growth during the period to understate the actual record because of the problems in the sample selection that affict the various bodies of data. Pirst, the eystematic under-counting of omaller establishments in the 1820 and 1832 samples should probably generate overestimates of the productivity levels in those gears. 20 In addition, the 
unrepresentative character of the amples from 1850 and 1860 vould be expected to gield underestimates. These two samples vere designed to ensure that there vere a certain minimum number of observations from each state that had surviving data, and hence suffer from a disproportionete representation of manufacturing firms from atates that bad relatively limited industrial development or mall populations (Atack, Bateman, and Weiss, 1979). As the firms from such states tended to be less productive than those from other areas, at least partially becaue of their omaller scales of operation, the levels of productivity estimated from the samples should be lover than those actually prevailing in the Northeast at the respective years. Moreover, the inclusion of part-time establishments in the aggregate data from the 1850 and 1860 censuses means that the estimates obtained from these cources are downard biased as well. Bence, with productivity levels overestimated for 1820 and underestimated for 1850 and 1860 , the rates of advance derived should be lower than those that were actually realized.

The above discussion has reviewed, in considerable detail, many of the features of the data cources and the estimation procedures that might have contributed to inaccurate or biased assesments of the productivity growth between 1820 and 1860 . It has been argued that moat of them would be expected to have led to estimates that were biased downward. The chief exception to this generaliration about the impacts of the potential biases is the effect of decline over time in the relative amount of manufacturing production carried out by firms 
operating seasonally. The disproportionate truncation of the least productive manufacturing establishments from the 1820 sample, however, should probably more than compensate for this problem, because the percentages dropped from the analysis for the thirteen industries sems likely to have exceeded those of firms that were part-time enterprises. Even if the adjustments underlying the $\underline{B}$ set of estimates, on which the discussion focuses, are not quite suffíicient, sensitivity ansiysis employing set $\underline{C}$ for 1820 indicates that the qualitative results would not be altered by any reasonable relaxation of the assumptions concerning the prevalence of seasonal operations in that year. 21 Particularly when one considers the net effect of all the biases, it appears likely that the estimates of productivity growth in manufacturing understates, on average, the actual record. The evidence seems to support the conclusion that labor productivity growth in manufacturing during this initial phase of industrialization was remarkably rapid and significantly higher than scholars may have previously reckoned. What is one to make of this performance? One possibility is to attribute the progress to the combined effects of a variety of related developments marking the period that include the introduction and diffusion of machinery, increases in capital and raw meterials intensity, changes in the organization of labor, the realization of scale economies, learning-by-doing, and the impact of expending markets through the selecting-out of inefficient producers and the stimulation of technical innovation. One might also explain the remarkably high rates of labor productivity 
growth a being at least partially accounted for by the evere contraction that occurred in the 0 . S. between 1816 and 1821 , and might have dragged productivity in 1820 vell below its trend level. Prom this perspective, the estimates could accurately reflect the actual amount of labor productivity growth between 1820 and 1860 , but convey a misleading impression about the long-term record.

Although cyclical effects might, in principle, have been large, the quelitative findings vitb respect to productivity growth over the entire period from 1820 to 1860 are not fundamentally altered vhen one makes adjustments for them. In order to gauge the potential magnitudes of the cyclical effect on manfacturing productivity, estimates of the trend over time in grose output per worker vere computed through regression analysis from the anual series on cotton textiles assembled by Davis and Stettler (1966) and by Layer (1955), and then the residuals were compared with the ABER classifications of cyclical behavior by gear (Thorp, 1926). Botb sets of residuals indicate some pro-cyclical variation, with the greatest deviations below trend in labor productivity being achieved, on average, one year before the trough of the business cycle. The Devis and stettler series implies much greater cyclical variation than the Layer series, but even here the effect sems somevhat modest. In the average business cycle, labor productivity, as messured by gross output per worker, fell to only 4.2 percent below trend during the year before the trough. 22 Moreover, over the limited period of time bpanned by their data, the magnitude of the deviation from trend does not appear to have been eystemstically 
related to the duration of the cycle. It is not clear whether cyclical variation in labor productivity sould be more or lese in cotton textiles than in other industries. Nevertbeless, even if the 4.2 percent figure is doubled and applied to all manufacturing industries, the adjustment for the business cycle in 1820 would not change the qualitative rebults concerning the pace of labor productivity growtb over the period under study. Such refinements vould be even leos significant for the other years covered by the data, because none of them seem to have been associated vith extreme cyclical activity. 23 It is apparent that taking cyclical factors into consideration does not appreciably alter the interpretation of the finding that these vere major increases in labor productivity across a vide range of manufacturing industries during the antebellum period. Not so clear, however, is the relative importance of the various contributors, such as capital deepening or mechanization, to these developments. That virtually all of the industries investigated realized impressive gains in labor productivity despite the rather modest degrees of mechanization and capital intensity in most of them, suggeste that other factors must have played a significant role. An indirect method of roughly gauging whether capital deepening or mechanization vere the principal determinants of the rate of progress is to examine whether the records of productivity growth of the capital- and machineryintensive industries compared favorably with those of their counterparts.

Instesd of treating the relationship between the factor 
TABLE 7

Indexes of Labor Productivity for

Clases of Manufacturing Industries: 1820 to 1860

\begin{tabular}{|c|c|c|c|c|c|c|c|c|}
\hline & \multicolumn{2}{|c|}{$\begin{array}{l}\text { Mechanized } \\
\text { Industries }\end{array}$} & \multicolumn{2}{|c|}{$\begin{array}{c}\text { Other } \\
\text { Industries }\end{array}$} & \multicolumn{2}{|c|}{$\begin{array}{l}\text { Capital-intensive } \\
\text { Industries }\end{array}$} & \multicolumn{2}{|c|}{$\begin{array}{c}\text { Otber } \\
\text { Industries }\end{array}$} \\
\hline & VIP & GQIP & VIP & GQLP & PLP & CQLP & VLP & GQIP \\
\hline 1820 & 100 & 100 & 100 & 100 & 100 & 100 & 100 & 100 \\
\hline $\begin{array}{l}1850 \\
(f \text { ism })\end{array}$ & 【183] & {$[246]$} & {$[153]$} & [165] & {$[177]$} & {$[230]$} & {$[156]$} & [173] \\
\hline $\begin{array}{c}1850 \\
\text { (agsregate) }\end{array}$ & 207 & 256 & 179 & 187 & 207 & 249 & 170 & 174 \\
\hline $\begin{array}{l}1860 \\
(\text { firm) }\end{array}$ & [231] & 【287] & {$[226]$} & [255] & [223] & [277] & [239] & [269] \\
\hline $\begin{array}{c}1860 \\
\text { (a8gregate) }\end{array}$ & 298 & 330 & 228 & 247 & 280 & 317 & 240 & 244 \\
\hline
\end{tabular}

Per Annum

Growtb Rates:

1820-1850 [1.8]-2.2 [2.7]-3.0 [1.5]-1.9 [1.7]-2.1 [1.7]-2.2 [2.5]-2.9 [1.5]-1.8 $1.8-[1.8]$

$1850-1860[2.8]-3.9[2.3]-2.7 \quad 2.6-[3.8] \quad 2.9-[4.6] \quad[2.7]-3.12 .5-[2.7] \quad 3.7-[4.2] \quad 3.6-[4.6]$

$1820-1860[2.0]-2.6[2.6]-2.9[2.1]-2.1 \quad 2.3-[2.4] \quad[1.9]-2.4[2.5]-2.8 \quad[2.2]-2.2 \quad 2.3-[2.5]$ 
Table 7

Notes and Sources: These estimates vere computed as veighted averages of the industry-specific figures underlying the indexes presented in Tables 4,5 and 6 . They vere calculated vitb the ame veights emploged in those tables to construct the veighted averages. However, the veights of the industries in eacb class vere normalized so that their sum was always equal to one. The mecbanized industries include cotton textiles, vool textiles, paper, glass, mills, and iron. The capitalintensive industries include cotton textiles, wool textiles, paper, mills, iron, liquors, and tanning. 
proportions employed and productivity growth through a discussion of the cases of individual industries, the thirteen industies were ranked by both capital intensity and machine intensity, on the basis of information pertaining to 1850 and 1832 respectively, and divided into two groups for each dimension. ${ }^{24}$ Weighted averages of the alternative measures of labor productivity were computed for the various classes of industries, and indexes and per anum rates of growth derived from them are presented in Table 7.

Several fịdings of interest emerge from tbese estimates. Perbaps most important is that, over the entire period from 1820 to 1860, all categories of industries registered major increases in labor productivity. It does apper, hovever, that the more capital-intensive and machinery-intensive industries generally realized omewhat larger advances, particularly in terms of GQLP. For example, in the more capitalintensive industries this measure of labor productivity rose by 177 to 217 (depending on whether the firm or aggregate data is employed) percent between 1820 and 1860 , whereas those less dependent on capital managed only 144 to 169 percent. This differential is consistent with the view that the utilization of machinery or capital equipment may bave facilitated changes in production processes that increased the rate at which raw material. could be processed into final producte with a given mount of labor.

What is rather puzzling bout these comparisone between the various classes of industries is that the qualitative results appear sensitive to whether the productivity estimates are derived from the 
samples of firm information or from the agregate data. Eapecially in 1860, the aggregate figures suggest much greater productivity growth in the capital-intensive and machinery-intensive industries, relative to their counterparts, than do the estimstes obtained from the firm reports. Since both cets of estimates would be expected to be biased downward, as discussed above, the substantial disparity might be thought to shed light on which sources of biases are most serious, and accordingly convey informstion about the structure of the manufacturing sector. In particular, it might seem to suggest that the disproportionste ampling of $f$ irms in 1860 from less-developed atates bisses the firm-level productivity estimates dowmard by more than the agregate productivity figures are affected by the incluaion of parttime operationa in the census totals. Such an explanation does not hold up well, bowever, to the observation that no industries other than tanning and perhaps cotton textiles have large discrepancies of the same sign between the firm- and aggregate-level productivity estimates in botb 1850 and 1860 . Instead, the sensitivity of the finding of higher productivity growth in the capital-intensive and machineryintensive industries to the choice between the two sets of estimates is primarily attributable to the enormous differences in 1860 for cotton textiles and paper that have not get been satisfactorily accounted for. 25

Regardless of the appropriate interpretation of the agnificantly more rapid progress of labor productivity implied by the aggregate data, one muat be impressed with the extent of the advances 
realized by those industries with low levels of capital or machinery intensity. By either messure of labor productivity, tbese industries managed growth rates of over 2.0 percent per annum. Despite the evidence that industries with a greater reliance on capital and machinery did slightly better, this strong record would seem to bear against the view that the increasing utilization of these factors of production per unit of labor were the dominant forces in accounting for, or encouraging, growth in manufacturing productivity during this early phase of industrialization.

One might legitimately challenge the persuasiveness of this argument, on the grounds that a comparison of the rates of productivity growth between classes of industries defined by their factor intensities at one moment in time does not bear directly on the iseue of how changes in the ratio of capital to labor over time contributed to advances in labor productivity. Such a procedure does, however, establish whether there was an asociation between the capital intensity of an industry at a point in time and the future capacity for, or bistory of, its productivity growtb (depending on whether capital intensity is measured at the beginning or end of the period in question), but that is amewhat different, if related, question. In this regard, the finding that the rates of advance achieved were nearly equal across classes of industries tends to suggest that any relationship between capital intensity and productivity growth was weak during this phase of industrial development. As alternative appoach to the problem of how important capital accumulation was in promoting 
productivity increase would be to formally evaluate how much of the growth in labor productivity over some epecified an of time can be directly attributed, in an accounting sense, to the accumulation of capital per unit of labor that occurred. Such an analysis entails the meaburement of total factor productivity, and will be carried out in the next section of the paper.

Another caveat to the interpretation of the comparisons between the rates of labor productivity growth in machinery- or capitalintensive industries and their counterparts is that the disparities are ignificanty maller for the entire period from 1820 to 1860 than thes are when attention is restricted to developments before 1850 . For example, the gap in the rate of increase of GQLP between the mechanized industries and the 1 ess mechsnized videns from between 2.6-2.9 and 2.3-2.4 percent per anum for 1820 to 1860 , to between 2.7-3.0 and 1.7-2.1 percent for 1820 to 1850 . This pattern reflects both impressive rates of advance throughout the period for all industries, and an acceleration from 1850 to 1860 that is especially pronounced among, and perhaps exclusive to, the less mechanized and capital-intenaive industries. The record of change in the capital to labor ratio is imilar, in that the less mechanized and the less capital-intensive industries experienced an extraordinary rise between 1850 and 1860 , while their counterparts failed to manifest any robust acceleration. This perspective on the evidence tends to place someuhat greater emphasis on the roles played by mechanization and capital accumulation in promoting labor productivity growth. The estimates can be viewed as 
consistent with the notion that the advances were initially most rapid among industries that mechanized, and were highly capital intensive, early, such as cotton textiles, and that the pace of progress in the rest of the manufacturing sector was boosted as sophisticated capital equipment began to be diffused more broadly during the $1840 \mathrm{~s}$ and $1850 \mathrm{~B}$. Nevertheless, it is also clear that many industries, such as hats and furniture/woodwork, realized substantial increases in productivity while they vere still utilizing small amounts of capital per unit of labor and little or no machinery.

The findings thus oupport the judgement that there may have been two general sources, or perhaps "stages", of productivity growth in manufacturing during early industrialization. The first wave of advances seems to have been associated, in many industries, with changes in the organization of labor and other alterations in production processes that did not involve large adjustments in the capital to labor ratio (Goldin and Sokoloff, 1982; Sokoloff, 1984b). The gains from these sorts of improvements were eventually to be exhausted, but a second class of innovations related to the introduction of sophisticated capital equipment followed, leading perhaps to an acceleration of labor productivity growth (Chandler, 1977; Atack, 1985). These stylized "stages" undoubtedly fail to describe the experience of all manufacturing industries; indeed, it is apparent that industries passed through them at different rates and periods, and that the timing of the diffusion of the new production methods may have varied across firms within industries with location 
and other characteristics. Moreover, changes in production techniques that encompassed aspects of both "stages" at once were implemented in some industries. It is difficult to determine precisely how important each development was in explaining labor productivity growth, particularly with only the bodies of evidence examined here. An exploration of more comprehensive measures of productivity should, however, help to improve our assessment of at least the relative significance of the various contributors. 
III

Although the estimates of labor productivity growth presented above are quite informstive about the record of industrisl development in the Nortbeast, broadening the investigation of productivity to include other factors as inputs can extend our knowledge furtber. It makes possible, in particular, the decomposition of the growti in iabor productivity between the smounts attributable to increases in capital and raw materials utilized per unit of labor, and that due to advances in total factor productivitg. Such information vill in turn contribute to our understanding of the evolution of production methods and belp to determine how important physical capital accumulation was during the early tages of industrialization.

It is useful to begin the treatment of total factor productivity by examining the indexes of real partial factor productivity reported in Table 8. These figures indicate the industryspecific movements over the period in the ratios of gross output to raw materials, capital, and labor. Several features of these estimates deserve comment. The first is that in nearly all industries, each of these ratios of partial factor productivity increses between 1820 and 1860. Although the liquors and tobacco industries do diverge Blightly from thi pattern, neitber case appears to contradict significantlg the general result as the decreases they manfest are small and sensitive to the choice between firm- and aggregate-level estimater. Since the index of total factor productivity is equivalent 
TABLE 8

Inderes of Real Partial Factor Productivity: 1820 to 1860

\begin{tabular}{|c|c|c|c|c|c|c|c|}
\hline & & 1820 & 1832 & $\begin{array}{c}1850 \\
\text { (firms) }\end{array}$ & $\begin{array}{c}1850 \\
(988 .)\end{array}$ & $\begin{array}{c}1860 \\
\text { (firms) }\end{array}$ & $\begin{array}{l}1860 \\
(288 .)\end{array}$ \\
\hline Boots/Sboes & $\begin{array}{l}G Q / R M \\
G Q / R \\
G Q / L\end{array}$ & $\begin{array}{l}100 \\
100 \\
100\end{array}$ & $\overline{-}$ & $\begin{array}{l}107 \\
181 \\
145\end{array}$ & $\begin{array}{l}113 \\
217 \\
145\end{array}$ & $\begin{array}{l}141 \\
115 \\
260\end{array}$ & $\begin{array}{l}156 \\
220 \\
230\end{array}$ \\
\hline $\begin{array}{l}\text { Coacbes/ } \\
\text { Bardesses }\end{array}$ & $\begin{array}{l}G Q / R M \\
G Q / R \\
G Q / L\end{array}$ & $\begin{array}{l}100 \\
100 \\
100\end{array}$ & $\begin{array}{r}121 \\
85 \\
86\end{array}$ & $\begin{array}{l}136 \\
206 \\
187\end{array}$ & $\begin{array}{l}154 \\
181 \\
158\end{array}$ & $\begin{array}{l}148 \\
126 \\
233\end{array}$ & $\begin{array}{l}155 \\
137 \\
194\end{array}$ \\
\hline $\begin{array}{l}\text { Cotton } \\
\text { Iertiles }\end{array}$ & $\begin{array}{l}G Q / B M \\
G Q / R \\
G Q / L\end{array}$ & $\begin{array}{l}100 \\
100 \\
100\end{array}$ & $\begin{array}{r}88 \\
124 \\
200\end{array}$ & $\begin{array}{r}68 \\
222 \\
336\end{array}$ & $\begin{array}{r}82 \\
269 \\
341\end{array}$ & $\begin{array}{l}112 \\
301 \\
267\end{array}$ & $\begin{array}{l}123 \\
219 \\
379\end{array}$ \\
\hline $\begin{array}{l}\text { Furaiture/ } \\
\text { Yoodvork }\end{array}$ & $\begin{array}{l}G Q / R M \\
G Q / R \\
G Q / L\end{array}$ & $\begin{array}{l}100 \\
100 \\
100\end{array}$ & $\begin{array}{r}91 \\
204 \\
138\end{array}$ & $\begin{array}{l}158 \\
304 \\
201\end{array}$ & $\begin{array}{l}181 \\
283 \\
225\end{array}$ & $\begin{array}{l}177 \\
225 \\
320\end{array}$ & $\begin{array}{l}178 \\
222 \\
309\end{array}$ \\
\hline Glas: & $\begin{array}{l}Q Q / R M \\
Q Q / R \\
Q Q / L\end{array}$ & $\begin{array}{l}100 \\
100 \\
100\end{array}$ & $\begin{array}{l}103 \\
179 \\
335\end{array}$ & $\overline{-}$ & $\begin{array}{l}155 \\
218 \\
305\end{array}$ & $=$ & $\begin{array}{l}140 \\
188 \\
290\end{array}$ \\
\hline Bate & $\begin{array}{l}G Q / R M \\
G Q / R \\
G Q / L\end{array}$ & $\begin{array}{l}100 \\
100 \\
100\end{array}$ & $\begin{array}{r}90 \\
163 \\
122\end{array}$ & $\begin{array}{r}96 \\
205 \\
223\end{array}$ & $\begin{array}{l}105 \\
242 \\
213\end{array}$ & $\begin{array}{l}113 \\
209 \\
328\end{array}$ & $\begin{array}{l}131 \\
284 \\
282\end{array}$ \\
\hline Iron & $\begin{array}{l}G Q / R M \\
G Q / K \\
G Q / L\end{array}$ & $\begin{array}{l}100 \\
100 \\
100\end{array}$ & - & $\begin{array}{l}127 \\
150 \\
105\end{array}$ & $\begin{array}{l}115 \\
125 \\
124\end{array}$ & $\begin{array}{l}119 \\
180 \\
218\end{array}$ & $\begin{array}{l}134 \\
142 \\
195\end{array}$ \\
\hline Iiquor: & $\begin{array}{l}C Q / R K \\
C Q / X \\
C Q / L\end{array}$ & $\begin{array}{l}100 \\
100 \\
100\end{array}$ & - & $\begin{array}{r}180 \\
83 \\
90\end{array}$ & $\begin{array}{l}148 \\
143 \\
187\end{array}$ & $\begin{array}{l}146 \\
114 \\
221\end{array}$ & $\begin{array}{r}157 \\
97 \\
209\end{array}$ \\
\hline $\begin{array}{l}\text { Flour/ } \\
\text { Grist Mille }\end{array}$ & $\begin{array}{l}Q Q / R H \\
G Q / R \\
C Q / L\end{array}$ & $\begin{array}{l}100 \\
100 \\
100\end{array}$ & - & $\begin{array}{l}137 \\
109 \\
166\end{array}$ & $\begin{array}{l}138 \\
131 \\
202\end{array}$ & $\begin{array}{l}143 \\
105 \\
224\end{array}$ & $\begin{array}{l}143 \\
107 \\
225\end{array}$ \\
\hline Paper & $\begin{array}{l}C Q / R M \\
G Q / R \\
G Q / L\end{array}$ & $\begin{array}{l}100 \\
100 \\
100\end{array}$ & $\begin{array}{r}51 \\
150 \\
275\end{array}$ & $\begin{array}{r}72 \\
372 \\
816\end{array}$ & $\begin{array}{l}71 \\
310 \\
783\end{array}$ & $\begin{array}{l}107 \\
455 \\
751\end{array}$ & $\begin{array}{r}119 \\
321 \\
1042\end{array}$ \\
\hline Tanning & $\begin{array}{l}C Q / R M \\
C Q / R \\
C Q / L\end{array}$ & $\begin{array}{l}100 \\
100 \\
100\end{array}$ & $\begin{array}{r}97 \\
93 \\
136\end{array}$ & $\begin{array}{r}95 \\
112 \\
180\end{array}$ & $\begin{array}{l}100 \\
143 \\
237\end{array}$ & $\begin{array}{l}117 \\
114 \\
217\end{array}$ & $\begin{array}{l}116 \\
117 \\
274\end{array}$ \\
\hline Tobacco & $\begin{array}{l}G Q / B M \\
G Q / R \\
G Q / L\end{array}$ & $\begin{array}{l}100 \\
100 \\
100\end{array}$ & $\begin{array}{r}116 \\
75 \\
130\end{array}$ & $\begin{array}{r}93 \\
114 \\
147\end{array}$ & $\begin{array}{r}80 \\
98 \\
145\end{array}$ & $\begin{array}{r}91 \\
80 \\
284\end{array}$ & $\begin{array}{l}132 \\
150 \\
178\end{array}$ \\
\hline $\begin{array}{l}\text { Yool } \\
\text { Textiles }\end{array}$ & $\begin{array}{l}\text { CQ/RM } \\
C Q / R \\
C Q / L\end{array}$ & $\begin{array}{l}100 \\
100 \\
100\end{array}$ & $\begin{array}{l}65 \\
145 \\
236\end{array}$ & $\begin{array}{r}75 \\
208 \\
262\end{array}$ & $\begin{array}{r}70 \\
169 \\
226\end{array}$ & $\begin{array}{l}128 \\
263 \\
401\end{array}$ & $\begin{array}{l}124 \\
252 \\
412\end{array}$ \\
\hline
\end{tabular}


Table 8

Notes and Sources: See the note to Table 1. The nominal values of the respective measures of partial factor productivity were converted to constant dollars with the industry-specific price indexes presented in Table 3. These estimates were then normalized relative to a base of 100 representing the respective industry" levels in 1820 . 
to aeighted average of these individual ratios, it is accordingly obvious that any reasonable measure of the former vould rise over the period in all industries.

Another pattern in the date that merits emphasis is that, in 211 industries, labor productivity increased much more over the period than either raw material or capital productivity. While the gains in labor productivity between 1820 and 1860 vere typically very large, the advances in raw materials productivity observed are quite modest. Capital productivity appears to bave generally increased leso than labor and more than raw material, productivity, altbougb there are a few prominent deviations from this pattern where it also failed to keep up witb the rise in the latter (i.e. liquors and flour/grist mills). This evidence suggests that, in general, manufacturing production methods evolved over time in such vays as to reduce the amounts of labor and, to a lesser extent, capital required to process a unit of raw merials into final product. It conforms vell with the vork of cholars who bave argued that many of the innovations introduced by manufacturers during this period vere intended to substitute relatively cheap raw materials for other inputs (Habakkuk, 1962).

By dividing GQ/L by $G Q / R$ or $G Q / R M$, one can calculate the change over time in the ratios of capital or raw materials to labor from the information provided in Table 8 . These latter ration indicate that northeastern manufacturing did abif somewhat toward nore capitalintensive production processes, a judged by the capital to labor 
ratio, between 1820 and 1860 . Bowever, the extent of this adjustment in factor proportions pales by comparison with the dramatic aurge in raw materials intensity that occurred contemporaneously. Whereas the weighted-average growth in the ratio of raw materials to labor was in the 118-127 percent range, the rise in capital per unit of labor sounted to only 67-72 percent. It is striking that both of these increases in the utilization of other inputs per unit of labor are proportionsliy much lower than the estimated groutb in CQLP during the period. This finding casts additional doubt on whether either raw material accumulation or capital accumulation, but eapecially the latter, could play the dominant role in expleining the advance in labor productivity.

There is, of course, ubstantial variation acrose the industries in the extent of the movement toward greater capital intensity, and some of them experienced significanty larger sbifts than the average did. Nevertbeless, as vill be show below, the increase in the ratio of capital to labor was not oufficiently massive in any industry to directly account for a mojor share of the progress realized in labor productivity. Horeover, it is interesting that the industries that undervent the most extensive capital deepening during the period may have been those that were most capital intenoive to begin vith. Industries such a liquors, flour/grist millo, paper, tanning, and wool textiles, which were among the seven most capital intensive of the thirteen in 1820 , appear to bave experienced the largest increases in the capital to labor ratio. Conversely, several 
of the less capital-intensive industries, boots/shoes, furniture/woodwork, and hats, were among those with the omallest percentage gains. Weighted averages of the two classes of industries reveal that the capital to labor ratio rose by 57-91 percent over the period in the more capital-intensive industries (as indentified at either 1820 or 1850 ), and by $16-95$ percent in their counterparts. Since the estimated range of increase for the former class of industries does not unambiguously dominate that for the latter, one cannot make an unqualified claim that those industries that were initially most capital intensive carried out more capital deepening. Nevertheless, it is clear that the classes of industries were not converging in their degrees of capital intensity, and that many remained highly labor intensive throughout the period. 26

A final point to make about the indexes of partial factor productivity is that they imply that the doubts some scholars have raised concerning the accuracy of the census valuations of the capital invested in manufacturing firms are unwarranted. The chief question about the usefulness of the reported capital input has been whether establishments included working capital in their statements to census enumerators. 27 If, as some have argued, they did not, then estimates of both the growth of capital intensity and of total factor productivity over time would likely be confounded. The possible seriousness of the problem can be evaluated with the more detailed information on the composition of capital investments contained in the 1832 sample drawn from the McLane Report. These date include separate 
assessments of the value of capital invested in land and atructurea, tools and machinery, and inventories (Sokoloff, 1984a).

Since the bulk of the capital investment was in vorking capital, and the 1832 estimates of total factor productivity and the capital to labor ratio vere based on valuations of the capital input that included inventories, one vould expect to observe some stark contrast between the estimates from that year and those from 1820 or 1850 if vorking capital had not been incorporated as part of the reported capital investments in the censuses of the other jears. More specifically, there vould be large decreases in total factor productivity and abstantial increases in capital intensity between 1820 and 1832, especially in those industries in which investment in working capital vas relatively important. No such patterns emerge, nor do the differentials in total factor productivity across industries, varying vith the relative investmente in fired and vorking capital, that would be evident in the 1820,1850 , and 1860 data if their information on capital investments did not include at least major component of the vorking capital. It thus seems unlikely that undervaluation of vorking capital in manufacturing censuses vas a serious defect, and correspondingly that the estimates of the growth in total factor productivity and capital intensity are significantly distorted as a consequence.

Indexes of real total factor productivity, based on the two alternative definitions of output, are presented for the thirteen industries in Tables 9 and 10. As with the labor productivity figures 
TABLE 9

Index of Total Factor Productivity:

Computed vitb Value $\Delta$ dded a the Hearure of Output

\begin{tabular}{|c|c|c|c|c|c|c|c|}
\hline & & 1820 & 1832 & $\begin{array}{l}1850 \\
(f i r m s)\end{array}$ & $\begin{array}{l}1850 \\
(988 .)\end{array}$ & $\begin{array}{l}1860 \\
\text { (fires) }\end{array}$ & $\begin{array}{l}1860 \\
(988 .)\end{array}$ \\
\hline Boots/Sboes & $\begin{array}{l}\mathbf{A} \\
\mathbf{B} \\
\mathbf{C}\end{array}$ & $\begin{array}{l}100 \\
100 \\
100\end{array}$ & $\begin{array}{l}- \\
-\end{array}$ & $\begin{array}{l}157 \\
144 \\
145\end{array}$ & $\begin{array}{l}179 \\
160 \\
154\end{array}$ & $\begin{array}{l}195 \\
175 \\
175\end{array}$ & $\begin{array}{l}240 \\
215 \\
206\end{array}$ \\
\hline $\begin{array}{l}\text { Coacbes/ } \\
\text { Barnesses }\end{array}$ & $\begin{array}{l}\mathbf{A} \\
\mathbf{B} \\
\mathbf{C}\end{array}$ & $\begin{array}{l}100 \\
100 \\
100\end{array}$ & $\begin{array}{l}94 \\
93 \\
93\end{array}$ & $\begin{array}{l}175 \\
181 \\
179\end{array}$ & $\begin{array}{l}191 \\
173 \\
171\end{array}$ & $\begin{array}{l}231 \\
210 \\
189\end{array}$ & $\begin{array}{l}216 \\
196 \\
193\end{array}$ \\
\hline $\begin{array}{l}\text { Cotton } \\
\text { Iextiles }\end{array}$ & $\begin{array}{l}\mathbf{A} \\
\mathbf{B} \\
\mathbf{C}\end{array}$ & $\begin{array}{l}100 \\
100 \\
100\end{array}$ & $\begin{array}{l}195 \\
174 \\
149\end{array}$ & $\begin{array}{l}188 \\
169 \\
186\end{array}$ & $\begin{array}{l}264 \\
235 \\
200\end{array}$ & $\begin{array}{l}269 \\
240 \\
224\end{array}$ & $\begin{array}{l}344 \\
306 \\
261\end{array}$ \\
\hline $\begin{array}{l}\text { Furaiturel } \\
\text { Woodvork }\end{array}$ & $\begin{array}{l}\mathbf{A} \\
\mathbf{B} \\
\mathbf{C}\end{array}$ & $\begin{array}{l}100 \\
100 \\
100\end{array}$ & $\begin{array}{l}134 \\
127 \\
121\end{array}$ & $\begin{array}{l}191 \\
198 \\
183\end{array}$ & $\begin{array}{l}248 \\
229 \\
210\end{array}$ & $\begin{array}{l}298 \\
288 \\
274\end{array}$ & $\begin{array}{l}303 \\
281 \\
257\end{array}$ \\
\hline Gleas & $\begin{array}{l}\mathbf{A} \\
\mathbf{c} \\
\mathrm{C}\end{array}$ & $\begin{array}{l}100 \\
100 \\
100\end{array}$ & $\begin{array}{l}227 \\
227 \\
216\end{array}$ & $\begin{array}{l}- \\
-\end{array}$ & $\begin{array}{l}258 \\
258 \\
249\end{array}$ & $=$ & $\begin{array}{l}233 \\
233 \\
225\end{array}$ \\
\hline Bats & $\begin{array}{l}\mathbf{A} \\
\mathbf{B} \\
\mathbf{C}\end{array}$ & $\begin{array}{l}100 \\
100 \\
100\end{array}$ & $\begin{array}{l}147 \\
130 \\
156\end{array}$ & $\begin{array}{l}201 \\
179 \\
213\end{array}$ & $\begin{array}{l}229 \\
203 \\
234\end{array}$ & $\begin{array}{l}253 \\
224 \\
254\end{array}$ & $\begin{array}{l}298 \\
264 \\
304\end{array}$ \\
\hline Iron & $\begin{array}{l}\mathbf{A} \\
\mathbf{B} \\
\mathbf{C}\end{array}$ & $\begin{array}{l}100 \\
100 \\
100\end{array}$ & $\begin{array}{l}- \\
-\end{array}$ & $\begin{array}{l}165 \\
128 \\
128\end{array}$ & $\begin{array}{l}203 \\
122 \\
112\end{array}$ & $\begin{array}{l}262 \\
170 \\
180\end{array}$ & $\begin{array}{l}289 \\
173 \\
159\end{array}$ \\
\hline Liquor: & $\begin{array}{l}\Delta \\
\mathbf{B} \\
\mathrm{C}\end{array}$ & $\begin{array}{l}100 \\
100 \\
100\end{array}$ & $\begin{array}{l}- \\
-\end{array}$ & $\begin{array}{l}121 \\
113 \\
122\end{array}$ & $\begin{array}{l}184 \\
160 \\
156\end{array}$ & $\begin{array}{l}173 \\
158 \\
174\end{array}$ & $\begin{array}{l}193 \\
168 \\
164\end{array}$ \\
\hline $\begin{array}{l}\text { Plour/ } \\
\text { Grist Hill: }\end{array}$ & $\begin{array}{l}\mathbf{A} \\
\mathbf{B} \\
\mathrm{C}\end{array}$ & $\begin{array}{l}100 \\
100 \\
100\end{array}$ & $\begin{array}{l}- \\
- \\
-\end{array}$ & $\begin{array}{r}109 \\
89 \\
95\end{array}$ & $\begin{array}{r}140 \\
112 \\
98\end{array}$ & $\begin{array}{l}140 \\
118 \\
121\end{array}$ & $\begin{array}{l}149 \\
119 \\
105\end{array}$ \\
\hline Paper & $\begin{array}{l}A \\
\mathbf{B} \\
\mathrm{C}\end{array}$ & $\begin{array}{l}100 \\
100 \\
100\end{array}$ & $\begin{array}{l}149 \\
147 \\
150\end{array}$ & $\begin{array}{l}466 \\
458 \\
422\end{array}$ & $\begin{array}{l}415 \\
408 \\
399\end{array}$ & $\begin{array}{l}440 \\
440 \\
487\end{array}$ & $\begin{array}{l}572 \\
563 \\
550\end{array}$ \\
\hline Tanging & $\begin{array}{l}\mathbf{A} \\
\mathbf{B} \\
\mathbf{C}\end{array}$ & $\begin{array}{l}100 \\
100 \\
100\end{array}$ & $\begin{array}{r}139 \\
114 \\
93\end{array}$ & $\begin{array}{l}168 \\
141 \\
127\end{array}$ & $\begin{array}{l}247 \\
201 \\
175\end{array}$ & $\begin{array}{l}157 \\
130 \\
121\end{array}$ & $\begin{array}{l}188 \\
153 \\
133\end{array}$ \\
\hline Tobacco & $\begin{array}{l}\mathbf{A} \\
\mathrm{B} \\
\mathrm{C}\end{array}$ & $\begin{array}{l}100 \\
100 \\
100\end{array}$ & $\begin{array}{l}- \\
-\end{array}$ & $\begin{array}{l}130 \\
126 \\
131\end{array}$ & $\begin{array}{l}96 \\
92 \\
88\end{array}$ & $\begin{array}{l}178 \\
171 \\
165\end{array}$ & $\begin{array}{l}224 \\
216 \\
206\end{array}$ \\
\hline $\begin{array}{l}\text { Wool } \\
\text { Textiles }\end{array}$ & $\begin{array}{l}\mathbf{A} \\
\mathbf{B} \\
\mathbf{C}\end{array}$ & $\begin{array}{l}100 \\
100 \\
100\end{array}$ & $\begin{array}{l}180 \\
141 \\
123\end{array}$ & $\begin{array}{l}227 \\
179 \\
157\end{array}$ & $\begin{array}{l}171 \\
134 \\
118\end{array}$ & $\begin{array}{l}332 \\
260 \\
212\end{array}$ & $\begin{array}{l}318 \\
248 \\
218\end{array}$ \\
\hline $\begin{array}{l}\text { Average } \\
\text { Weigbted } \\
\text { Upweighted }\end{array}$ & $\begin{array}{l}\mathbf{B} \\
\mathbf{B}\end{array}$ & $\begin{array}{l}100 \\
100\end{array}$ & $\begin{array}{l}{[126]} \\
{[132]}\end{array}$ & $\begin{array}{l}{[162]} \\
{[177]}\end{array}$ & $\begin{array}{l}182 \\
191\end{array}$ & $\begin{array}{l}{[203]} \\
{[207]}\end{array}$ & $\begin{array}{l}231 \\
241\end{array}$ \\
\hline
\end{tabular}


Table 9

Notes and Sources: These estimates of total factor productivitg vere computed over the ame sets of observations as the corresponding labor productivity estimates presented in Table 1 and 4 vere. See the notes to Tables 1 and 4. The index of total factor productivity for the weighted average of the industries was computed with the same weights, and in the ame manner, as the index of labor productivity reported in the latter table. The output elasticities employed in the computation were elected from a range derived by estimating Cobb-Douglas production functions over each cross-sectional sample. These regressions gielded estinates of the capital coefficient between 0.25 and 0.30 . The latter value vas employed bere so so to increase the estimate of the input: in the later gears relative to the earlier. The formulation of total factor productivity employed bere is:

$$
\mathrm{NFP}=\left(\nabla A / \mathrm{K}^{0.30} L_{2}^{0.70}\right)
$$

where NFP is aesure of total factor productivity utilizing value added as the measure of output, VA is value added, $x$ is the value of the capital invested, and $I$ is the labor input. The calculations of NFP were performed after the values of gross output, raw materials, and capital had been deflated to constant dollars, utilizing the price indexes reported in Table 3 . These "real" estimates of total factor productivity vere then normalized relative to an 1820 etandard of 100 . 
TABLE 10

Iodex of Total Factor Productivity:

Computed witb Gross Output as the Meceure of Output

\begin{tabular}{|c|c|c|c|c|c|c|c|}
\hline & & 1820 & 1832 & $\begin{array}{l}1850 \\
(f i r m s)\end{array}$ & $\begin{array}{c}1850 \\
(088 .)\end{array}$ & $\begin{array}{l}1860 \\
(f i r e)\end{array}$ & $\begin{array}{c}1860 \\
(a 88 .)\end{array}$ \\
\hline Boots/Shoes & $\begin{array}{l}A \\
B \\
C\end{array}$ & $\begin{array}{l}100 \\
100 \\
100\end{array}$ & $\begin{array}{l}- \\
-\end{array}$ & $\begin{array}{l}133 \\
127 \\
125\end{array}$ & $\begin{array}{l}142 \\
134 \\
129\end{array}$ & $\begin{array}{l}178 \\
168 \\
165\end{array}$ & $\begin{array}{l}196 \\
185 \\
179\end{array}$ \\
\hline $\begin{array}{l}\text { Coacbes/ } \\
\text { Barnesces }\end{array}$ & $\begin{array}{l}A \\
B \\
C\end{array}$ & $\begin{array}{l}100 \\
100 \\
100\end{array}$ & $\begin{array}{l}104 \\
104 \\
104\end{array}$ & $\begin{array}{l}157 \\
160 \\
158\end{array}$ & $\begin{array}{l}166 \\
159 \\
158\end{array}$ & $\begin{array}{l}175 \\
168 \\
159\end{array}$ & $\begin{array}{l}172 \\
164 \\
163\end{array}$ \\
\hline $\begin{array}{l}\text { Cotton } \\
\text { Textiles }\end{array}$ & $\begin{array}{l}\mathbf{A} \\
\mathbf{B} \\
\mathbf{C}\end{array}$ & $\begin{array}{l}100 \\
100 \\
100\end{array}$ & $\begin{array}{l}128 \\
121 \\
112\end{array}$ & $\begin{array}{l}141 \\
134 \\
133\end{array}$ & $\begin{array}{l}157 \\
149 \\
136\end{array}$ & $\begin{array}{l}180 \\
170 \\
164\end{array}$ & $\begin{array}{l}203 \\
192 \\
176\end{array}$ \\
\hline $\begin{array}{l}\text { Furniture/ } \\
\text { Woodwork }\end{array}$ & $\begin{array}{l}\mathbf{A} \\
\mathbf{B} \\
\mathbf{C}\end{array}$ & $\begin{array}{l}100 \\
100 \\
100\end{array}$ & $\begin{array}{l}122 \\
116 \\
114\end{array}$ & $\begin{array}{l}184 \\
186 \\
179\end{array}$ & $\begin{array}{l}217 \\
206 \\
197\end{array}$ & $\begin{array}{l}229 \\
222 \\
218\end{array}$ & $\begin{array}{l}232 \\
220 \\
211\end{array}$ \\
\hline Glas: & $\begin{array}{l}\mathbf{A} \\
\mathbf{B} \\
\mathbf{C}\end{array}$ & $\begin{array}{l}100 \\
100 \\
100\end{array}$ & $\begin{array}{l}163 \\
163 \\
160\end{array}$ & $\begin{array}{l}- \\
-\end{array}$ & $\begin{array}{l}202 \\
202 \\
201\end{array}$ & $\begin{array}{l}- \\
-\end{array}$ & $\begin{array}{l}185 \\
185 \\
183\end{array}$ \\
\hline Bat: & $\begin{array}{l}\mathbf{A} \\
\mathbf{B} \\
\mathbf{C}\end{array}$ & $\begin{array}{l}100 \\
100 \\
100\end{array}$ & $\begin{array}{l}115 \\
108 \\
118\end{array}$ & $\begin{array}{l}148 \\
140 \\
153\end{array}$ & $\begin{array}{l}157 \\
148 \\
159\end{array}$ & $\begin{array}{l}185 \\
174 \\
186\end{array}$ & $\begin{array}{l}199 \\
187 \\
201\end{array}$ \\
\hline Irod & $\begin{array}{l}A \\
B \\
C\end{array}$ & $\begin{array}{l}100 \\
100 \\
100\end{array}$ & $\begin{array}{l}- \\
-\end{array}$ & $\begin{array}{l}137 \\
122 \\
124\end{array}$ & $\begin{array}{l}151 \\
119 \\
115\end{array}$ & $\begin{array}{l}187 \\
153 \\
157\end{array}$ & $\begin{array}{l}193 \\
153 \\
147\end{array}$ \\
\hline Liquors & $\begin{array}{l}A \\
B \\
C\end{array}$ & $\begin{array}{l}100 \\
100 \\
100\end{array}$ & $\begin{array}{l}- \\
-\end{array}$ & $\begin{array}{l}134 \\
129 \\
134\end{array}$ & $\begin{array}{l}170 \\
159 \\
157\end{array}$ & $\begin{array}{l}169 \\
162 \\
168\end{array}$ & $\begin{array}{l}173 \\
162 \\
160\end{array}$ \\
\hline $\begin{array}{l}\text { Flour/ } \\
\text { Grist Mills }\end{array}$ & $\begin{array}{l}\Delta \\
B \\
C\end{array}$ & $\begin{array}{l}100 \\
100 \\
100\end{array}$ & $\begin{array}{l}- \\
- \\
-\end{array}$ & $\begin{array}{l}156 \\
142 \\
148\end{array}$ & $\begin{array}{l}173 \\
155 \\
150\end{array}$ & $\begin{array}{l}173 \\
159 \\
160\end{array}$ & $\begin{array}{l}178 \\
160 \\
154\end{array}$ \\
\hline Paper & $\begin{array}{l}\mathbf{A} \\
\mathbf{B} \\
\mathbf{C}\end{array}$ & $\begin{array}{l}100 \\
100 \\
100\end{array}$ & $\begin{array}{l}103 \\
102 \\
103\end{array}$ & $\begin{array}{l}203 \\
200 \\
192\end{array}$ & $\begin{array}{l}192 \\
190 \\
188\end{array}$ & $\begin{array}{l}246 \\
245 \\
256\end{array}$ & $\begin{array}{l}280 \\
277 \\
273\end{array}$ \\
\hline Tanging & $\begin{array}{l}\mathbf{A} \\
\mathbf{B} \\
\mathbf{C}\end{array}$ & $\begin{array}{l}100 \\
100 \\
100\end{array}$ & $\begin{array}{r}118 \\
107 \\
98\end{array}$ & $\begin{array}{l}129 \\
120 \\
115\end{array}$ & $\begin{array}{l}153 \\
139 \\
131\end{array}$ & $\begin{array}{l}155 \\
143 \\
138\end{array}$ & $\begin{array}{l}169 \\
154 \\
145\end{array}$ \\
\hline Tobacec & $\begin{array}{l}A \\
\mathbf{B} \\
\mathbf{C}\end{array}$ & $\begin{array}{l}100 \\
100 \\
100\end{array}$ & $\begin{array}{l}- \\
-\end{array}$ & $\begin{array}{l}113 \\
111 \\
114\end{array}$ & $\begin{array}{r}102 \\
100 \\
98\end{array}$ & $\begin{array}{l}132 \\
130 \\
128\end{array}$ & $\begin{array}{l}151 \\
148 \\
145\end{array}$ \\
\hline $\begin{array}{l}\text { Hool } \\
\text { Textiles }\end{array}$ & $\begin{array}{l}\mathbf{A} \\
\mathbf{B} \\
\mathbf{C}\end{array}$ & $\begin{array}{l}100 \\
100 \\
100\end{array}$ & $\begin{array}{l}124 \\
110 \\
103\end{array}$ & $\begin{array}{l}146 \\
130 \\
122\end{array}$ & $\begin{array}{l}130 \\
115 \\
108\end{array}$ & $\begin{array}{l}231 \\
205 \\
187\end{array}$ & $\begin{array}{l}227 \\
202 \\
190\end{array}$ \\
\hline $\begin{array}{l}\text { Average } \\
\text { Weighted } \\
\text { Dnueigbted }\end{array}$ & $\begin{array}{l}\mathbf{8} \\
\mathbf{B}\end{array}$ & $\begin{array}{l}100 \\
100\end{array}$ & $\begin{array}{l}{[109]} \\
{[113]}\end{array}$ & $\begin{array}{l}{[136]} \\
{[148]}\end{array}$ & $\begin{array}{l}144 \\
152\end{array}$ & $\begin{array}{l}{[170]} \\
{[171]}\end{array}$ & $\begin{array}{l}178 \\
184\end{array}$ \\
\hline
\end{tabular}


Table 10

Notes and Sources: These estimates of total factor productivity vere computed over the same sets of observations as the corresponding labor productivity estimates preserved in Table 2 and 5 were. See the notes to those tables. The index of total factor productivity for the veighted average of the industies was computed with the same veights, and in the ame manner, as the index of labor productivity reported in Table 5. The output elasticities were selected from a range provided by Cobb-Douglas production functions estimsted cross-sectionally. The choice was influenced by the desire to bave the coefficient for capital and ray materials to be on the high aide so as to depress the estimated rates of productivity growth. The formulation of total factor productivity employed bere is:

$$
\operatorname{TPP}=\left(\operatorname{CQ} / \mathrm{RM}^{0.54} L^{0.33} \mathrm{~K}^{0.13}\right)
$$

where IFP is aesure of total factor productivity utilizing the gross value of output as the messure of output, BM is the value of $r$ w materials, $L$ is the labor input, and. $K$ is the value of capital invested. All of the relevant variables vere deflated to constant dollars, by the indexes in Iable 3, before the calculation vere performed. These "real" estimates of total factor productivity vere then normalized relative to a 1820 standard of 100 . 
reported above, the estimates were computed for each of three sets of sub-samples of firms so as to demonstrate the insensitivity of the results to the extent of adjustment for part-time firms, and the price indezes appearing in Table 3 vere employed to convert the nominal measures of gross output, value added, raw materials, and capital to constant dollars before productivity was calculated.

The results indicate that by either of the two measures, nearly all industies realized ubstantial growth in total factor productivity between 1820 and 1860 . Weighted averages of the records of the individual industries gield estimated increases ranging from 103 to 131 percent with output is defined as value added (KFP) and from 70 to 78 percent by the alternative gauge (IFP). Each industry performed vell by at least one mesure. Flour/grist mills registered the smsllest advance in IFP, only 18 to 19 percent, but the estimated gain in IFP approached 60 percent; and although tobacco ranked at the bottom in terms of progress in IFP, its increases of $30-48$ percent in that

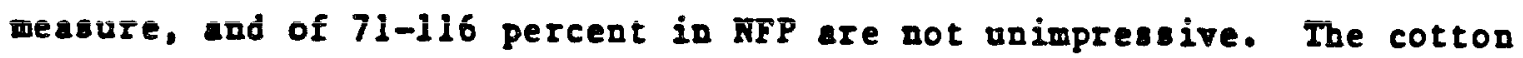
textiles, wool tertiles, and paper industries are among those attaining the largest estimated increases in total factor productivity, but major gains were also achieved by industries such as furniture/woodwork and hats, which were among the least capital intensive and mechanized throughout the period. These figures provide dramatic testimony to bow dynamic the manufacturing sector was during the early steges of industrialization. Moreover, they serve to undercut the bypotbeais that capital accumulation was the driving force behind productivity growth 
during this era. The substantial increases in total factor productivity demonstrate clearly that the bulk of the gains in labor productivity cannot be directly accounted for by capital or raw materials deepening within manufacturing firms. In addition, the wide range of industries that shared in this general advance of productivity suggests that the phenomenon can not be attributed to developments such as the diffusion of new and more sophisticated capital equipment, which touched only a relatively limited number of industries until late in the period.

The consistency of the finding of large gains in total factor productivity, across industries and measures, bolsters confidence in the robustness of the qualitative result. Moreover, as the minor differences between the $\underline{C}$ and $\underline{B}$ sets of estimates suggest, the basic picture that emerges is not sensitive to any reasonable adjustments of the sub-samples to account for the existence of part-time establishments. 28 It is also encouraging to note that there are fewer implausible fluctuations in these estimates than in the indexes of labor productivity, particularly with the IFP measure. Several industries do continue to manifest strange records of progress, but in at least the most troubling cases, paper, tanning, and tobacco, the price indexes relied on are suspect and likely the primary source of the problems. The other questionable features may also be attributable to the inappropriate or defective nature of the price series utilized, or an inadequate number of observations in some years. Whatever the explanation for these anomalies, however, the fundamental results do 
TABLE 11

Growtb Rates of Total Pactor Productivity

in Selected Manufacturing Industries: 1820 to 1860

\begin{tabular}{|c|c|c|c|c|c|}
\hline & & $\frac{1820-1832}{2}$ & $\frac{1820-1850}{2}$ & $\frac{1850-1860}{z}$ & $\frac{1820-1860}{2}$ \\
\hline Boots/Shoes & $\begin{array}{l}\text { IFP } \\
\text { IPP }\end{array}$ & - & $\begin{array}{l}1.3-1.6 \\
0.8-1.0\end{array}$ & $\begin{array}{l}1.9-2.9 \\
2.9-3.3\end{array}$ & $\begin{array}{l}1.4-2.0 \\
1.3-1.6\end{array}$ \\
\hline $\begin{array}{l}\text { Coacbea/ } \\
\text { Barnessea }\end{array}$ & $\begin{array}{l}\operatorname{TFP} \\
\operatorname{TPP}\end{array}$ & $\begin{array}{r}-0.7 \\
0.3\end{array}$ & $\begin{array}{l}1.9-2.1 \\
1.6-1.6\end{array}$ & $\begin{array}{l}1.2-1.5 \\
0.3-0.5\end{array}$ & $\begin{array}{l}1.7-1.9 \\
1.3-1.3\end{array}$ \\
\hline $\begin{array}{l}\text { Cotton } \\
\text { Iextiles }\end{array}$ & $\begin{array}{l}\text { TFP } \\
\text { TTP }\end{array}$ & $\begin{array}{l}5.2 \\
1.8\end{array}$ & $\begin{array}{l}1.8-3.0 \\
1.0-1.4\end{array}$ & $\begin{array}{l}2.7-3.6 \\
2.4-2.6\end{array}$ & $\begin{array}{l}2.3-2.9 \\
1.4-1.7\end{array}$ \\
\hline $\begin{array}{l}\text { Furaiture/ } \\
\text { Woodwork }\end{array}$ & $\begin{array}{l}\text { ITPP } \\
\text { TPP }\end{array}$ & $\begin{array}{l}2.2 \\
1.4\end{array}$ & $\begin{array}{l}2.4-2.9 \\
2.2-2.5\end{array}$ & $\begin{array}{l}2.1-3.8 \\
0.7-1.8\end{array}$ & $\begin{array}{l}2.7-2.8 \\
2.0-2.1\end{array}$ \\
\hline Glas: & $\begin{array}{l}\text { RTP } \\
\text { ITP }\end{array}$ & $\begin{array}{l}7.7 \\
4.5\end{array}$ & $\begin{array}{l}3.3 \\
2.5\end{array}$ & $\begin{array}{l}-1.0 \\
-0.9\end{array}$ & $\begin{array}{l}2.2 \\
1.6\end{array}$ \\
\hline Bate & $\begin{array}{l}\text { IFP } \\
\text { ITP }\end{array}$ & $\begin{array}{l}2.4 \\
0.7\end{array}$ & $\begin{array}{l}2.0-2.3 \\
1.2-1.4\end{array}$ & $\begin{array}{l}2.3-2.7 \\
2.2-2.4\end{array}$ & $\begin{array}{l}2.1-2.5 \\
1.4-1.6\end{array}$ \\
\hline Irod & $\begin{array}{l}\text { IFP } \\
\text { ITP }\end{array}$ & - & $\begin{array}{l}0.7-0.8 \\
0.6-0.7\end{array}$ & $\begin{array}{l}2.9-3.6 \\
2.3-2.5\end{array}$ & $\begin{array}{l}1.4-1.4 \\
1.1-1.1\end{array}$ \\
\hline Liquor: & $\begin{array}{l}\text { MPP } \\
\text { IFP }\end{array}$ & - & $\begin{array}{l}0.4-1.6 \\
0.9-1.6\end{array}$ & $\begin{array}{l}0.5-3.5 \\
0.2-2.3\end{array}$ & $\begin{array}{c}1.2-1.3 \\
1.2\end{array}$ \\
\hline $\begin{array}{l}\text { Flour/ } \\
\text { Grist Mills }\end{array}$ & $\begin{array}{l}\text { ITP } \\
\text { ITP }\end{array}$ & - & $\begin{array}{r}-0.4-0.4 \\
1.2-1.5\end{array}$ & $\begin{array}{l}0.6-2.8 \\
0.3-1.2\end{array}$ & $\begin{array}{l}0.4-0.4 \\
1.2-1.2\end{array}$ \\
\hline Paper & $\begin{array}{l}\text { MPP } \\
\text { TIPP }\end{array}$ & $\begin{array}{l}3.6 \\
0.2\end{array}$ & $\begin{array}{l}5.0-5.4 \\
2.2-2.4\end{array}$ & $\begin{array}{r}-0.4-3.3 \\
2.0-3.8\end{array}$ & $\begin{array}{l}3.9-4.5 \\
2.3-2.6\end{array}$ \\
\hline Tanning & $\begin{array}{l}\text { MFP } \\
\text { IPP }\end{array}$ & $\begin{array}{l}1.2 \\
0.7\end{array}$ & $\begin{array}{l}1.2-2.4 \\
0.6-1.1\end{array}$ & $\begin{array}{c}-2.7--0.8 \\
1.1-1.8\end{array}$ & $\begin{array}{l}0.7-1.1 \\
0.9-1.1\end{array}$ \\
\hline Tobacco & $\begin{array}{l}\operatorname{MPP} \\
\operatorname{ITP}\end{array}$ & - & $\begin{array}{r}-0.3-0.8 \\
0.0-0.4\end{array}$ & $\begin{array}{l}3.1-8.9 \\
1.5-4.0\end{array}$ & $\begin{array}{l}1.4-2.0 \\
0.7-1.0\end{array}$ \\
\hline $\begin{array}{l}\text { Nool } \\
\text { Textiles }\end{array}$ & $\begin{array}{l}\operatorname{MTP} \\
\operatorname{IFP}\end{array}$ & $\begin{array}{l}3.2 \\
0.9\end{array}$ & $\begin{array}{l}1.0-2.0 \\
0.5-0.9\end{array}$ & $\begin{array}{l}3.8-6.4 \\
4.7-5.8\end{array}$ & $\begin{array}{l}2.4-2.5 \\
1.8-1.9\end{array}$ \\
\hline $\begin{array}{l}\text { Weighted } \\
\text { Average }\end{array}$ & $\begin{array}{l}\operatorname{mPP} \\
\operatorname{IPP}\end{array}$ & $\begin{array}{l}{[1.8]} \\
{[0.8]}\end{array}$ & $\begin{array}{l}{[1.5]-1.9} \\
{[1.0]-1.2}\end{array}$ & $\begin{array}{l}\{2.3\}-2.4 \\
{[2.2]-2.2}\end{array}$ & $\begin{array}{l}\{1.7\}-2.0 \\
{[1.3]-1.8}\end{array}$ \\
\hline
\end{tabular}


Table 11

Notes and Sources: These per annum rates of total factor productivity growth were computed from the set $\underline{B}$ estimates reported in Iables 9 and 10. See the noter to those tables. The NFP estimates are of the growth of total factor productivity measured with value added as output. The TFP estimates are based on the measure of total factor productivity that employs gross output as the measure of output and explicitly treats the value of raw materials a en input. 
not depend upon their inclusion in the manufacturing averagea. Estimates of the per annum growth rates of total factor productivity have been computed from the inderes reported in Tables 9 and 10 for the entire period between 1820 and 1860 , as well as for ceveral sub-periods. They are presented in Table 11, and confirm that - vide spectrum of manufacturing industries in the Northeast enjoyed rapid progrese in total factor productivity during this initial phase of industrialization. Indeed, the veighted-average per annum growth rates for these thirteen industries metch, if not exceed, the performance of the $D$. S. economy during other perioda. Between 1820 and 1860, Dortheastern manufacturing appears to bave achieved per annum rates of increase of 1.7-2.0 percent in MFP and 1.3-1.8 in ITP. These figures might be compared to the 1.8 percent rate for MFP estimated by Rendrick (1961) for the national manufacturing sector between 1869 and 1953, or to the $0.8-0.9$ and 1.4 percent rates computed by Gallman (1986) for the annual increase in IFP for the economy at large during the respective periods 1840-1900 and 1900-1960. Although some might react to the application of these sandards by rejecting the early manufacturing rates of advance as implausibly high, it should be remembered that one would expect the pace of productivity growth in the most dynamic sector of the most burgeoning region during the period to have urpased that for the national economy or for 0 . 8. manufacturing in total. Bence, the finding that northeastern manufacturing might have realized faster rates of total factor productivity increase during its initial burst of expansion than economy-wide averages, pertaining 
to the ame or other periods, hould perhaps not be too surprising.

These estimates further sugsest, as did those for labor productivity growth, that productivity rose, on average, more sowly between 1820 and 1850 than during the $1850 \mathrm{~s}$. The average rate of advance in IFP, for example, increased from 1.5-1.9 percent per annum over the first thirty years to 2.3-2.4 percent during the later ten. The pattern of acceleration is, admittedly, somewhat veaker if one focuses on the contrat between 1820-1832 and 1832-1860, and only on those industries for which 1832 figures are available. Hevertheless, even here, the weight of the evidence seems to favor a mild increase in the pace of total factor productivity growth. Many researchers bave contended that ouch an acceleration ma have resulted from a opurt in the accumulation of more and better capital equipment, during the $1840 \mathrm{~s}$ and 1850 (Chandler, 1977; David, 1977; Williamoon and Lindert, 1980). They might tend to argue that the process of capital deepening only sems unimportant, because the conventional measures of inputs fail to fully detect the technical change that is embodied in newer vintages of capital. The acceleration of total factor productivity growth during a decade of more rapid diffusion of machinery is certainly consistent with this interpretation, but alterative exploretion of this feature of the economic record are also available. 29

Although some of technical change realized between 1820 and 1860 was undoubtedly embodied in capital goods, there are several reasons to doubt whether a proper accounting for this phenomenon would be capable of reversing the qualitative conclusion concerning the 
agnificance of capital accumulation for productivity growtb in early manufacturing. First, even if one were to ascribe as mach as half of the acceleration in total factor productivity increase to improvements of manufacturing capital not reflected in its price, the amount of productivity growth so generated vould be quite small relative to the total realized over the entire period. One might claim that more of the estimated advance in total factor productivity sould be credited to embodied technical change unincorporated in price, but the rationale for this appears veak. Hot only did the less capital-intenaive and less mechanized industries do quite vell before the purported consequential developments of the 1840, and 1850, but their invertments in machinery and tools per unit of labor remined quite omall in ebsolute terms, as vell as in relation to their total investment in capital, at the end of the period. Even nost of the counterpart industies, classified as more mechanized and capitalintensive, had rather modest absolute and relative amounts invested in capital equipment that was directly involved in production (Sokoloff; 1984a). Given that manfacturing industries bad the bulk of their investment in structures and inventories, there vould seem to be severe limits on the amount of embodied technical change that the capital input could plausibly be endoved with. 30

One approach to evaluating the importance of embodied technical change is to compare the records of total factor productivity growth between the more capital-intensive and the les capital intensive industries, or between the more mechanized and les: 
TABLE 12

Inderes of Total Pactor Productivity for Classes of Madufacturing Industries: 1820 to 1860

\begin{tabular}{|c|c|c|c|c|c|c|c|c|}
\hline & \multicolumn{2}{|c|}{$\begin{array}{l}\text { Mecbanized } \\
\text { Industries }\end{array}$} & \multicolumn{2}{|c|}{$\begin{array}{c}\text { Otber } \\
\text { Industries }\end{array}$} & \multicolumn{2}{|c|}{$\begin{array}{c}\text { Capital-intensive } \\
\text { Industies }\end{array}$} & \multicolumn{2}{|c|}{$\begin{array}{c}\text { Otber } \\
\text { Industies }\end{array}$} \\
\hline & NFP & IFP & MFP & IFP & $\overline{m P}$ & TTP & $\mathbf{F F} \mathbf{P}$ & $\operatorname{IFP}$ \\
\hline 2820 & 100 & 100 & 100 & 100 & 100 & 100 & 100 & 100 \\
\hline $\begin{array}{l}1850 \\
(\mathrm{firm})\end{array}$ & [168] & {$[137]$} & [155] & {$[134]$} & {$[160]$} & $\lfloor 134\rfloor$ & {$[164]$} & [143] \\
\hline $\begin{array}{c}1850 \\
\text { (ag85egate) }\end{array}$ & 182 & 142 & 181 & 147 & 181 & 142 & 182 & 151 \\
\hline $\begin{array}{l}1860 \\
(f i r m)\end{array}$ & {$[217]$} & {$[172]$} & {$[186]$} & {$[166]$} & $|205|$ & [169] & {$[200]$} & [173] \\
\hline $\begin{array}{c}1860 \\
\text { (ag85egate) }\end{array}$ & 250 & 180 & 209 & 176 & 232 & 176 & 229 & 186 \\
\hline
\end{tabular}

\footnotetext{
Per Lopum
}

Growtb Rates:

$1820-1850[1.6]-1.8[1.1]-1.2[1.5]-2.0[1.0]-1.3 \quad[1.4]-1.9[1.0]-1.2[1.7]-2.0[1.2]-1.4$ $1850-1860 \quad[2.8]-3.3[2.3]-2.4 \quad 1.4-[1.7] 1.8-[2.1] \quad 2.3-[2.5] 2.2-[2.3] \quad[1.8]-2.4[2.0]-2.2$ $1820-1860 \quad[1.9]-2.2[1.4]-1.5[1.5]-1.9[1.3]-1.4 \quad[1.7]-2.0[1.3]-1.4[1.7]-2.1[1.4]-1.6$ 
Table 12

Notes and Sources: These estimates vere computed as veighted averages of the industry-specific figures presented underlying the indexes presented in Tables 9, 10, and 11. The weighted avereges vere constructed with the system of weighting employed in Table 7 . See the notes to those tables. 
mechanized ones. The logic underlying this procedure is that where new vintages of capital are endowed with embodied technical change, the measured increase over time in the inputs utilized by firms vill be lower, relative to the outputs produced, and hence, measured total factor productivity higher. Given that one would expect the realization of technical change embodied in capital and not incorporated in its price to be associated with either the ize of the capital input relative to other inputs, or the change in that relative size of the capital input over the period in question, the nore capital-intenaive and mechanized industries might seem likely to have enjoyed greater total factor productivity growth than the other if this component of embodied technical change was of much quantitative aignificance. 31 Although, as discussed above, the evidence of significantly more capital deepening over the period by these classes of industries is not entirely robust, it is clear that they did employ larger amounts of capital and machinery per unit of labor throughout the period, and carried out at leat a much capital deepening a their lese capitalintensive and mechanized counterparte did. One vould, accordingly, expect them to exbibit nore total factor productivity growth.

When one examines the indexes of total factor productivity presented in Table 12 for classes of manufacturing industries, hovever, only minor differences in performance emerge. 32 The diecrepancies in the mount of productivity growth realized between the aore and less capital-intensive industries are trivial in magnitude and vary in oign with the choice between measures. As for the other oystem of 
IABLE 13

Decomponition of the Growtb in Grose Output per Zquivalent Horker Between Proportions Accounted for by Increases in Capital Inteneity, Law Materialo Intensity, and Total Factor Productivity: 1820 to 1860

\begin{tabular}{|c|c|c|c|c|}
\hline & & $\begin{array}{c}\text { \& Due } \\
\text { to } \Delta(L / L)\end{array}$ & $\begin{array}{l}\text { Z Due } \\
\text { to } \Delta(\mathrm{RM} / \mathrm{L})\end{array}$ & $\begin{array}{l}\text { I Due } \\
\text { to } \Delta \text { TTP }\end{array}$ \\
\hline Boot:/Sboe: & $\begin{array}{l}\mathbf{F} \\
\mathbf{A}\end{array}$ & 112 & $\begin{array}{l}348 \\
25\end{array}$ & $\begin{array}{l}547 \\
74\end{array}$ \\
\hline $\begin{array}{l}\text { Cosches' } \\
\text { Barneaves }\end{array}$ & $\begin{array}{l}\mathbf{F} \\
\mathbf{4}\end{array}$ & $\begin{array}{l}9 \\
7\end{array}$ & $\begin{array}{l}29 \\
19\end{array}$ & $\begin{array}{l}61 \\
74\end{array}$ \\
\hline $\begin{array}{l}\text { Cotton } \\
\text { Iextiles }\end{array}$ & $\mathbf{F}$ & $\begin{array}{r}-2 \\
5\end{array}$ & $\begin{array}{l}48 \\
46\end{array}$ & $\begin{array}{l}54 \\
49\end{array}$ \\
\hline $\begin{array}{l}\text { Furniture/ } \\
\text { Woodvork }\end{array}$ & $\mathbf{F}$ & $\begin{array}{l}4 \\
4\end{array}$ & $\begin{array}{l}27 \\
26\end{array}$ & $\begin{array}{l}68 \\
70\end{array}$ \\
\hline Glas: & $\begin{array}{l}F \\
4\end{array}$ & 5 & $3 \overline{7}$ & 57 \\
\hline Bato & $\begin{array}{l}P \\
\mathbf{A}\end{array}$ & $\begin{array}{l}5 \\
0\end{array}$ & $\begin{array}{l}49 \\
40\end{array}$ & $\begin{array}{l}46 \\
60\end{array}$ \\
\hline Iron & $\begin{array}{l}\mathbf{P} \\
\mathbf{A}\end{array}$ & $\begin{array}{l}3 \\
6\end{array}$ & $\begin{array}{l}42 \\
30\end{array}$ & $\begin{array}{l}55 \\
63\end{array}$ \\
\hline Liquors & $\begin{array}{l}F \\
4\end{array}$ & $\begin{array}{l}11 \\
14\end{array}$ & $\begin{array}{l}28 \\
21\end{array}$ & $\begin{array}{l}61 \\
65\end{array}$ \\
\hline $\begin{array}{l}\text { Flour/ } \\
\text { Griet Mille }\end{array}$ & $\begin{array}{l}\mathbf{F} \\
4\end{array}$ & $\begin{array}{l}12 \\
12\end{array}$ & $\begin{array}{l}30 \\
30\end{array}$ & $\begin{array}{l}57 \\
58\end{array}$ \\
\hline Peper & $\begin{array}{l}\mathbf{F} \\
4\end{array}$ & $\begin{array}{l}3 \\
6\end{array}$ & $\begin{array}{l}52 \\
50\end{array}$ & $\begin{array}{l}44 \\
43\end{array}$ \\
\hline Ianging & $\begin{array}{l}\mathbf{T} \\
\mathbf{A}\end{array}$ & $\begin{array}{l}11 \\
11\end{array}$ & $\begin{array}{l}43 \\
46\end{array}$ & $\begin{array}{l}46 \\
43\end{array}$ \\
\hline Tobacco & 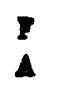 & $\begin{array}{r}16 \\
4\end{array}$ & $\begin{array}{l}59 \\
28\end{array}$ & $\begin{array}{l}25 \\
68\end{array}$ \\
\hline $\begin{array}{l}\text { Wool } \\
\text { Textiles }\end{array}$ & $\mathbf{Y}$ & $\begin{array}{l}4 \\
5\end{array}$ & $\begin{array}{l}44 \\
46\end{array}$ & $\begin{array}{l}31 \\
49\end{array}$ \\
\hline
\end{tabular}


Table 13

Notes and Sources: The decomposition of the growtb in grose output per equivalent worker was based on the accounting information:

$$
G^{\star} L P=I F P^{\star}+0.13(R / L)+0.54(R M / L) \text {, }
$$

where * ignifies a derivative of the log. The decomposition applies to the firms included in the $\underline{B}$ sub-samples. See the notes to Tables 5 and 8 . 
classification, the more mechanized industries do seem to bave experienced higher rates of advance than the less mechanized did. However, these disparities are omall relative to the rates of increase, particularly when TFP serves as the gauge for total factor productivity. Another feature of these estimstes that bears against the hypothesis that much of the technical change realized vas embodied in physical capital and not reflected in its price is the relative decline in the rate of total factor productivity growth of the less mechanized and capital-intenaive industries, as compared to their counterpart classes, between the sub-periods 1820-1850 and 1850-1860. 4s already alluded to, the rates of increase of both capital intensity and labor productivity accelerated abarp between the two sub-periods among the former classes of industries relative to the latter. 33 If the capital investments involved considerable embodied technical change, then one vould expect a relative increase in the pace of total factor productivity in less mechanized and capital-intensive industries to have accompanied the relative ourge in capital deepening and labor productivity.

\section{Regardless of how persuasive these argument for questioning} the extent of embodied technical change are, it is informative to decompose the growth over the period in gross output per equivalent worker between the amounte directly attributable, in an accounting sense, to increases in capital intenaity $(R / L)$, in raw aterialo intensity (RM/L), and in total factor productivity (TFP). The results of such a procedure are reported in Table 13, with separate estimates 
presented for the estimstes obtained from the firm data and those from the agregate data. They indicate that in most industries the increase between 1820 and 1860 in capital intensity explains less than 10 percent of the growth in labor productivity as measured by GQP. Indeed, in no case does the abre exceed 16 percent. Advances in total factor productivity, on the otber hand, appear to be the principal force bebind labor productivity growth, generally accounting for over balf of the increase in GQLP and never belov 25 percent. 34 These findings dramatize bow remarkably limited the importance of capital deepening was in generating labor productivity growth during early industrialisation. They imply that if capital accumulation played a oubstantial role at all, it vas due to improvements in capital that vere not reflected in price. Given the basis for skepticiom about the extent to which technical progress was embodied in capital outlined above, other sources of total factor productivity, and thus of labor productivity, growth vould appear to deserve more attention. 
This paper has relied on four cross-sections of manufacturing firm data to atudy the growth of labor and total factor productivity during early industrialization in the D. S.. Although the bodies of evidence analyzed suffer from some defects, the procedures employed in constructing the estimates vere designed to deal with the problems and yield growth rates that would be biased downard. Despite this concern for producing conservative estimates, the results indicate that a wide range of msnufacturing industries realized major increases in botb labor and total factor productivity as early as the 1820 s, and continued to do so, at an accelerated pace, through 1860. The breadth, magnitude, and timing of the edvances observed suggest that the northeastern manufacturing sector was a dynamic one, whose productivity growth, perhaps coupled with imilar gains in agriculture, fueied the process of industrialization in that region. The evidence would seew to make it increasingly difficult to sustain the view that the onset of industrial expansion in the Northeast was primarily due to the release of labor and other resources from a tagnant and declining agricultural sector.

Of perbaps even greater interest, the estimates imply that increases in total factor productivity, sometimes referred to a the residual, accounted for most of the advance in labor productivity between 1820 and 1860 . The deepening of capital, in contrast, appears to have made only a modest contribution. Although it is possible that 
a major share of the growth in the residual over the period consisted of technical change embodied in capital equipment, which would enhance the significance of capital in explaining the gains in productivity, the shreds of evidence that can be gleaned from these data do not support this notion. Capital accumulation may indeed have had important influences on the course of early industrial development, such as through allowing for the extension of the transportation network and other social overhead capital, but the introduction of sophisticated capital equipment and capital deepening in general were evidently not as central to the initial phase of industrialization as they have sometimes been depicted. On the contrary, the material examined here seems to suggest that other sources of measured productivity growth in manufacturing, including the changes in labor organization and the intensification of work that have been emphasized in recent studies, played the leading roles (Lazonick and Brush, 1985; Goldin and Sokoloff, 1982; Sokoloff, 1984b). Although many questions remain, the results also appear to be consistent with, if not to actually support, the view that the expansion of markets that accompanied the onset of industrialization unleashed powerful forces that acted to raise productivity. At least in the U. S., preindustrial manufacturing seems to have had the potential, which it was ultimately to realize, for substantial gains in efficiency without major additions to the stock of capital equipment. 
FOOTNOTES

* This paper was substantially revised during the year following the presentation at the Williamsburg Conference. The author thus had the opportunity to take full advantage of the penetrating comments he received from Jeffrey Williamson, and the excellent advice offered by Robert Allen, Paul David, Lance Davis, Stanley Engerman, Robert Fogel, Gerald Friedman, Robert Gallman, Peter Lindert, and Thomas Weiss. He also benefited from seminar discussions of early versions of the paper at Northwestern Oniversity, U.C.L.A., the University of British Columbia, the University of Chicago, and the All-University of California Conference in Economic History, held in Los Angeles in May 1985. He is grateful to James Lin for careful research assistance, and to the California Institute of Technology, where he was a Visiting Assistant Professor during the reworking of the paper, for research support. Grants from the U.C.L.A. Academic Senate and the Foundation for Research in Economics and Education are also acknowledged.

1. Nearly all studies of productivity growth during this period have been based on information that was either highly aggregated or drawn from only to a small number of cotton textile firms (David, 1967, 1975, 1977; Davis and Stettler, 1966; Gallman, 1972a, 1972b, 1986 ; Layer, 1955; McGouidrick, 1968 ; Nickle8s, 1979; Williamson, 1972). 
2. Each of the data sets suffers from problems of sample selection bias. The coverage of the 1820 Census of Manufactures and the McLane Report differed substantially by geographic region and size of establishment, with an apparent net result of an undersampling of smaller, and accordingly less productive, firms. The design of the samples from 1850 and 1860 led to a disproportionate representation of firms from states with limited industrial development. See Sokoloff (1982) and Atack, Bateman, and Weiss (1979) for details on the characteristics of these samples. Since the sample selection biases are likely to raise the estimated productivity levels for 1820 and 1832 , and reduce them in 1850 and 1860 , the rates of productivity growth computed from these sources should understate the actual record.

3. The industrial classification system employed in the 1850 Census was in general adopted, but several of the industry definitions industries used here include two or more of the 1850 categories. The reluctance to combine data from different industries stemed from a concern about the possibility of confusing increases over time in labor productivity within industries with variation in the estimates due to changes in industrial composition.

4. This generalization about the reporting practices of part-time establishmets is based primarily on an examination of the 
schedules for roughly 200 firms in the 1820 and 1832 samples that specified the fractions of the year they were in operation. Rather than expunging observations of seasonal enterprises from the calculations, one would of course prefer to have accurate assessments of their inputs and outputs to work with so that their levels of performance would be reflected in the estimates. It is likely that part-time firms, whose relative importance declined over time, were indeed less efficient producers than their fulltime counterparts. Accordingly, to the extent that the adjustments in the composition of the sub-samples do succeed in excluding all part-time establishments from consideration, the estimates of productivity growth might tend to understate the advances realized over the period by failing to pick up the perhaps important gains to the economy of displacing seasonal operators with full-time producers.

5. It is admittedly unclear what fractions of manufacturing firms in the various years were operating significantly fewer than 50 weeks per year (full-time). A general sense of the orders of magnitude has, however, been obtained from the reports by many firms in 1832 of the fraction of the year they were in operation, from an examination of the cross-sectional distributions of establishments by industry, size, wage rates, and location, as well as from inspections of the distributions of firms by measures of total factor produrtivity. The gpproach adopted in preparing the three 
sets of estimates was not to attempt a precise delineation of the proportion of firms operating part-time in the individual years, but rather to demonstrate that no plausible assumptions about the changes in their relative numbers would reverse the qualitative findings. Although ad hoc in nature, this manner of displaying the patterns in the data appears effective. One can check the sensitivity of the industry-specific results by comparing the figures from the three sets of estimates, or by evaluating the $\underline{C}$ figures for 1820 with respect to the $\underline{B}$ figures for the later years. The extent of the allowance for the decreasing prevalence of part-time firms implied by this latter comparison appears to be extremely generous.

6. In this paper, such sumaries of the quantitative results are based on the choice of the 1860 estimates computed from the aggregate data as the standard for that yesr.

7. The weights employed to construct the averages consist of the industry shares of total northeastern value added and gross output respetively in 1850 , and were calculated from U. S. Census Bureau (1858). The two point estimates available for twelve of the industries in 1850 and 1860 , as well as the growth rates they enter into, will henceforth be expressed as a range of estimates (i.e. 72-112 percent). 
8. The general robustness of the results is apparent from the observation that the estimates of labor productivity in 1820 are greatly affected by the shift from the $\underline{B}$ sub-sample to the $\underline{C}$ in only a few industries. The value-added figures are considerably more sensitive to the subset of establishments employed in the calculations, but even by this measure, only three of the industries have their levels of labor productivity raised by as much as 15 percent.

9. Of greatest concern in this regard are the glass, liquors, and tobacco industries. All of these industries are characterized by having estimates based on very few observations in at least one of the years. Random variation in the estimates due to this source may magnify the impact of sample selection bias in some cases. For example, the extremely high levels of productivity estimated for the glass industry in 1832 is probably related to their being computed from information on a rather small number of glass-making enterprises in Massachusetts. The most advanced plants in that industry were located in Massachusetts (Davis, 1949), and that state accounted for a disproportionste share of the firms included in the McLane Report.

10. The 1850 and 1860 samples were designed to ensure that each state accounted for a certain minimum number of observations. This feature of their collection led to an over-sampling of 
manufacturing firms from amaller and less-developed states such as Maine, Vermont, and New Hampshire. The establishments located in such states operated, on average, at lower levels of productivity. Accordingly, one would expect that this source of sample selection bias would lead to underestimates of productivity. In principle, one should be able to correct for this sample selection problem by re-weighting the observations. In practice, however, inconsistent evidence from the aggregate census reports and the firm samples on the industrial composition of state manufacturing sectors suggests that there are other defects in the samples that confound the identification of the appropriate set of weights.

11. It is, of course, important to recognize that the great majority of the price series pertain to only a single output or raw material of the respective industries. Hence, they undoubtedly introduce errors, and must be applied with caution. The four industries for which raw materials indexes could not be retrieved are coaches/harnesses, glass, hats, and iron. The Wholesale Price Index constructed by Warren and Pearson was employed as a reasonable substitute in these cases, because it behaves more like the average of the other raw materials Beries than the alternative general indexes. Another deficiency is that in two industries, tobacco and tanning, the author was compelled to rely on basically the same price index for both outputs and raw materials. It is especially unfotuuate that separate indexes could not be obtained 
for these industries, because the indexes, which pertain primarily to the price of raw materials, move quite erratically. Additional information on whether the prices of outputs and raw materials in each of these industries actually followed such peculiar paths would be quite helpful. It seems likely that the extraordinary variability in these price indexes accounts for at least some of the irregular movements in the productivity growth estimates for these industries.

12. In cases where there were several alternative price indexes available, the most conservative, with respect to the estimation of the increase in productivity over time, were generally selected.

13. This suggests that a significant portion of the variability in the labor productivity estimates is due to sharp changes in the factor proportions utilized.

14. The extreme decline in the price index for paper output invites skepticism. However, it should be noted that the general stability between 1820 and 1860 in the ratio of gross output to raw materials in that industry would seem to uggest that the output price index might not be far off in terms of the extent of the decrease over the entire period.

15. As was mentioccl atovi, the price indexes for tanning and tobacco 
fluctuate wildy, particularly between 1859 and 1860. The erratic behavior of the index for "hides and leather" may also affect estimates for boots/shoes, because that series serves as the index for raw materials in that industry, as well as for both outputs and raw materials in tanning.

16. The argument presented in this paragraph applies to estimates of productivity growth that employ value added as the measure of output. Hence, it supplies a rationale for why the value-added figures might indicate less advance over the period than those relying on gross output as the appropriate measure of product. Given the uncertainty about the accuracy of the individual price indexes, however, any conclusions about the relative performance of two industries, regardless of the measure of productivity referred to, should be offered tentatively.

17. There are, admittedly, some scholars who judge part-time operations to be the rule during the early stages of industrialization, rather than the exception. Moreover, few would expect there to be many firms in industries such as flour/grist mills that were in production all year. Nevertheless, the enumerators for the Mclane Report indicated that the overwhelming majority of the establishments included in that survey claimed to be in operation for at least 50 weeks a year. Although the level of production in any individual firm may have been characterized 
by enormous seasonal variation, there might have been tasks that required at least some workers to be employed throughout the gear. As long as enterprises in such circumstances reported their average labor and capital inputs, they should, for our purposes, have been classified as full-time operators and included in the subsets of firms over which the estimates were prepared.

18. As is apparent from the evidence presented in Goldin and Sokoloff (1982), the ratio of female to adult male wages increased from roughly the $0.25-0.35$ range in 1820 to roughly the $0.45-0.55$ range in 1850 and beyond. Hence, to the extent that the wage ratio reflects the average relative productivity of the two groups, it might be argued that employing the same weights in all years leads to overestimates of the mount of productivity growth. The issue turns, however, on whether the change in the relative productivity of females is due to variation over time in the age or skill composition of workers, or to some other factors. In any case, wide range of weights for females and boys were tested, and the general qualitative results were found to be insensitive to reasonable variation in them.

19. It was further assumed that in no industry at 1850 or $1860 \mathrm{did}$ boys account for more than 33 percent of the male labor force. Such a constraint, probably serves to bias upward the estimates of the labor injut for beveral industries. This ceiling on the 
proportion of males who were boys was introduced as another way of ensuring that the estimates of the labor input in the later years would err on the high side, if at all.

20. This would be expected, because of the scale economies present in most manufacturing industries (Sokoloff, 1984b). The bias is likely to have been greater in the 1832 sample, because Massachusetts firms accounted for a highly disproportionate share of the enterprises covered by that survey, and generally were larger and had higher than average levels of measured productivity.

21. For example, the weighted average of the industry rate of growth in gross output per equivalent worker, as computed from the $\underline{C}$ estimates for 1820 and the $\underline{B}$ estimates for 1860 , ranges between 2.3 and 2.5 percent per annum. These figures are only slightly lower than the 2.5 to 2.7 range derived from the employment of the B estimates for both years.

22. The Davis and Stettler series might be expected to yield estimates of the variation in output per worker over the business cycle that were downard biased, because their figures pertain to output per man-hour. See Davis and Stettler (1966).

23. One caveat to this generalization is that the iron and steel industry afpedio to have been quite depressed during the late 
$1840 \mathrm{~s}$ and early 1850s. See Temin (1964).

24. The industries were ordered in terms of capital intensity by the information on their aggregate capital to labor ratios in the Northeast obtained from U. S. Census Bureau (1858), and then divided into groups. The same classification of industries is derived from the 1820 firm data. The ranking by machinery intensity was computed from information contained in the 1820 and 1832 samples of firm data, particularly the latter, as well as in U. S. Census office (1895). Industries were placed in categories on the basis of estimates of the investment in machinery per unit of labor computed for 1832 .

25. The cotton textile establishments in the firm samples were, on average, also smaller and substantially less capital intensive than their counterparts in the aggregate data. Their levels of total factor productivity were, however, not much lower. The massive disparity in measured labor productivity may accordingly be due to the less-developed states, which were over-represented in the samples, being characterized by a much different system or type of cotton manufacture.

26. It must also be admitted that these indexes of partial factor productivity not infrequently exhibit irregular, if not implausibie, movements from one point in time to another, as well 
as discrepancies between the firm and aggregate level estimates for 1850 and 1860 . Just as was contended above in discussing the labor productivity figures, many of the former type of problems may be due to inaccurate price inderes, excessive variability in point estimates because of amall number of observations, or sample selection biases. The disparities between the independent estimates for 1850 and 1860 are disturbing, but they might again be partially explained by many of the firm-level estimates being based on the characteristics of relatively few firms located in unrepresentative areas. These anomalies in the data indicate that much caution should be exercised in drawing conclusions, particularly with respect to changes over short periods, but they do not justify a blanket dismissal of the results.

27. The other principal issue has concerned whether firms reported the gross value of their capital investment or the net value. Recent work has tended to agree that some net measure of the capital stock was being reflected in the figures. See Gallman (1986) and Sokol off (1984a).

28. If one computes the weighted-average growth in total factor productivity from the $\underline{C}$ figures for 1820 and the $\underline{B}$ figures for 1860 , the estimates decline only 81 ightly. NFP rises by 87 to 113 percent over the period, while TFP increases by 63 to 71 percent. 
29. One could, for example, explain the acceleration in total factor productivity as arising from the expansion of product markets, which stimulated changes in the organization of production within the firm, technical change, and intra-regional specialization between the more urbanized counties and the outlying areas within the Nortbeast (Lindstrom, 1978; Sokoloff, 1984b).

30. Although it is difficult to imagine that variation in the relatively small amount of tools and machinery per worker could account for much of the large changes observed in productivity, it would be helpful to know, by industry, how the former ratio moved over time. Unfortunately, of all the data sets being examined here, only the 1832 sample contains the detailed information on the composition of capital necessary to estimate the ratio. It seems likely, however that the percentage changes in machinery and tools per equivalent worker would resemble the course of the capital to labor ratio, because the hares of capital invested in tools and machinery had not been altered much by 1890 (Sokoloff, 1984a; D. S. Census office, 1895 ).

31. This conjecture does not necessarily hold, but if all else was constant, one would expect it to. The chief obstacles or objections to its applicability probably concern the variation across industries in the rates at which capital goods depreciated, 
old vintages vere replaced by new, and output increased over the period. The complication arising from this later situation is that the industries that grew most rapidly would tend to benefit relatively more from technical change embodied in capital even if their capital to labor ratios were low and hadn't changed much, because a greater proportion of their capital stock would consist of new-vintage items.

32. A series of pooled cross-section production functions vere estimated with various measures of output serving as the dependent variable, and measures of the inputs, year dumies, industry dummies, class dumies, and interactions appearing as independent variables. When variables for the interaction between dummies for the more mechanized or capital-intensive industries and the year 1860 were included in the specifications, the coefficients on them generally failed to indicate that these classes of industries realized ignificantly more productivity growth between 1820 and 1860.

33. For example, the per annum rates of growth of capital per equivalent worker between 1820 and 1850 were $0.9-1.2$ percent and $-0.1-+0.1$ percent for the more and less mechanized industries respectively. During the next decade, the less mechanized industries experienced a sharp acceleration in their absolute and relative rates of increase of this variable to 4.0-6.8 percent per 
annum, as compared to the $0.7-2.3$ percent pace registered by their counterparts.

34. If one decomposes the growth in value added per equivalent worker, the qualitative result is the same. Increases in the capital to labor ratio directly account for only a small fraction of the progress realized, leaving most of the rise in labor productivity to be explained by advances in total factor productivity. 
REFERENCES

Atack, Jeremy (1985). "Industrial Structure and the Emergence of the Modern Industrial Corporation." Explorations in Economic History, 22.

Atack, Jeremy, Fred Bateman and Thomas Weiss (1979). "An Evaluation of Nineteenth Century Censuses As Sources of Economic Statistics." Paper delivered to the Cliometrics Conference, Chicago, Illinois.

Brady, Dorothy S. (1964). "Relative Prices in the Nineteenth Century." The Journal of Economic Bistory, 24.

- (1966). "Price Deflators for Final Product Estimates." In Dorothy S. Brady (ed.), Output, Employment, and Productivity in the United States After 1800. Studies in Income and Wealth 30 . New York: National Bureau of Economic Research.

Chandler, Alfred D. (1977). The Visible Hand: The Managerial Revolution in American Business. Cambridge, Massachusetts: Barvard Oniversity Press.

Cole, Arthur H. (1938). Wholesale Commodity Prices in the United States, 1700-1861. Volume II. Cambridge, MA: Harvard University Pres6. 
Cole, Arthur H. and Walter B. Smith (1935). Fluctuations In American Business, 1790-1860. Cambridge, MA: Harvard University Press.

David, Paul A. (1967). "The Growth of Real Product in the Onited States Before 1840: New Evidence, Controlled Conjectures." The Journal of Economic History, 27.

- (1975). Technical Choice, Innovation and Economic Growth. New York: Cambridge University Press.

- (1977). "Invention and Accumulation in America"s Economic Growth: A Nineteenth Century Parable." In Rarl Brunner and Allan Meltzer (eds.), International Organization, National Policies and Economic Development. Amsterdam: North Holland.

Davis, Lance E. and Robert E. Gallman (1978). "Capital Formation in the United States During the Nineteenth Century" in Peter Mathiss and M. M. Postan (eds.), The Cambridge Economic History of Europe. Volume VII, Part 2. Cambridge, ENG: Cambridge Oniversity Press.

DaviB, Lance E. and H. Louis Stettler III (1966). "The New England Textile Industry, 1825-60: Trends and Fluctuations." In Dorothy S. Brady, (ed.), Output, Employment, and Productivity in the United States After 1800 . Studies in Income and Wealth 30 . New York: Netjonal Burezu of Economic Research. 
Davis, Pearce (1949). The Development of the American Glass Industry. Cambridge, Massachusetts: Harvard Oniversity Press.

Gallman, Robert E. (1972a). "Changes in Total O. S. Agricultural Factor Productivity in the Nineteenth Century." Agricultural History, 46.

- (1972a). "The Pace and Pattern of American Economic Growth." In Lance Davis et. al., American Economic Growth. New York: Harper and Row.

- (1983). "How Do I Measure Thee? Let Me Count the Ways: Investment and the Capital Stock in the Nineteenth Century." Paper delivered to the Caltech/Weingart/Social Science History Association Conference: The Variety of Quantitative History, Pasadear, California.

- (1986). "The U. S. Capital Stock in the Nineteentb Century." In Stanley Engerman and Robert Gallman (eds.), Long= Term Factors in American Economic Growth. Chicago: University of Chicago Press.

Goldin, Claudia and Kenneth Sokoloff (1982). Women Children, and Industrialization in the Early Republic: Evidence from the Manufacturing Cersuses," The Journal of Economic Bistory, 42. 
Habakkuk, H. J. (1962). American and British Technology in the Nineteenth Century: The Search for Labour-Saving Inventions. Cambridge, ENG.: At the University Press.

Rendrick, John W. (1961). Productivity Trends in the United States. Princeton: Princeton University Press.

Landes, David S. (1969). The Unbound Prometheus: Technological Change and Industrial Development in Western Europe from 1750 to the Present. Cambridge, England: At the University Press. - (1985). "What Do Bosses Really Do?" Harvard University: Mimeo.

Layer, Robert G. (1955). Earnings of Cotton Mill Operatives, 18251914. Cambridge, MA: Harvard Dniversity Presis.

Lazonick, William and Thomas Brush (1985). "The 'Horndahl Effect' in Early U. S. Manufacturing." Explorations in Economic History, 22.

Lebergott, Stanley (1964). Manpower in Economic Growth: The American Record Since 1800. New York: McGraw-Bill.

Lindstrom, Diane (1978). Economic Development in the Philadelphia Region, 1810-1850. New York: Columbia Oniversity Press. 
McCloskey, Donald (1981). "The Industrial Revolution 1780-1860: A Survey." In Donsld McCloskey and Roderick Floud (eds.), The Economic History of Britain Since 1700. Volume I Cambridge, ENG: Cambridge Dniversity Press.

McGouldrick, Paul (1968). New England Textiles in the 19th Century. Profits and Investments. Cambridge, MA: Barvard Dniversity Pres8.

Marglin, Stephen A. (1974). What Do Bosses Do? The Origins and Functions of Hierarchy in Capitalist Production." The Reviev of Radical Political Economics, 6.

Nickles8, Pamela J. (1979). "A New Look at Productivity in the New England Cotton Textile Industry, 1830-1860." The Journal of Economic Bistory, 39.

Smith, Adam (1976). An Inquiry into the Nature and Causes of the Wealth of Nations. Chicago: Oniversity of Chicago Press. Originally published in 1776.

Sokoloff, Renneth L. (1982). "Industrialization and the Growth of the Manufacturing Sector in the Northeast, 1820-1850." Unpublished Ph.D. dissertation, Harvard University. 
- (1983). "The Growth of Real Wages in Northeastern Manufacturing, 1820-1850." Paper delivered to Social Science History Association, Washington, D. C..

- (1984a). "Investment in Fixed and Working Capital During

Early Industrialization: Evidence from U. S. Manufacturing

Firms." The Journal of Economic Bistory, 44.

Temin, Peter (1968). Iron and Steel in Nineteenth Century America: An Economic Inquiry. Cambridge, MA: M. I. T. Press.

Thorp, Willard L. (1926). Business Annals. New York: Nationsl Bureau of Economic Research.

U. S. Bureau of the Census (1975). Historical Statistics of the Onited States, Colonial Times to 1970. Washington, D. C.: Government Printing office. 
U. S. Census Office (1858). Abstract of the Statistics of Manufactures, According to the Returns of the Seventh Censug. Washington, D. C.; Government Printing Office.

- (1865). Eighth Census of the D. S. 1860: Manufactures. Washington, D. C.: Government Printing Office.

- (1895). Eleventh Census of the Onited States: 1890. Report on the Manufacturing Industries in the United States.

Washington D. C.: Government Printing Office.

D. S. House of Representatives (1833). Documents Relative to the Statistics of Manufactures in the ㅁ. S. 2 vols. Washington D. C.: Duff Green.

Williamson, Jeffrey G. (1972). "Embodiment, Disembodiment, Learning By Doing and Constant Returns to Scale in the Nineteenth-Century Cotton Textiles." The Journal of Economic History, 32.

Williamson, Jeffrey G. and Peter H. Lindert, (1980). American Inequality: A Macroeconomic History. Nev York: Academic Press. 